\title{
Evaluación in vitro de la formación de biopelículas de bacterias marinas del Caribe colombiano
}

\section{Evaluation in vitro of biofilm formation with marine bacteria from Colombian Caribbean}

\author{
Sofía López ${ }^{1}$, Sven Zea y Javier Gómez-León ${ }^{2}$ \\ (D) $0000-0002-8508-819$ (D) $0000-0002-5657-4877$ (D) $0000-0001-5015-7071$ \\ 1. Universidad Nacional de Colombia - Sede Caribe - Instituto de Estudios en Ciencias del Mar-Cecimar, Atte. Invemar, Calle 25 \# 2-55, El Rodadero, \\ Santa Marta,Colombia.sslopezp@unal.edu.co; sezeas@unal.edu.co \\ 2. Instituto de Investigaciones Marinas y Costeras - Invemar [Marine and Coastal Research Institute]. Calle 25 \# 2-55 El Rodadero, Santa Marta, \\ Colombia.javier.gomez@invemar.org.co
}

\section{RESUMEN}

$\mathrm{L}$ a formación de biopelículas es un proceso importante para las comunidades bacterianas marinas debido a que este mecanismo favorece la adaptación a variaciones en las condiciones ambientales. El objetivo de este estudio fue evaluar la formación de biopelículas de las bacterias aisladas de sedimentos marinos en condiciones in vitro. Para esto se realizaron ensayos de cuantificación de biopelículas usando dos métodos, cristal violeta y reducción del colorante XTT; además se evaluó la viabilidad de las bacterias mediante la tinción Live/Dead. Posteriormente las cepas evaluadas fueron identificadas usando el marcador 16S ARN. Los resultados mostraron que los aislados pertenecen al género Bacillus todos en diferentes rangos fueron capaces de formar películas y se seleccionaron las cepas B. safensis 64181 y Bacillus sp 64186 las cuales indicaron mayor producción de esta. Los ensayos a diferentes temperaturas demostraron que para las cepas seleccionadas la mejor temperatura fue de $28^{\circ} \mathrm{C}$. Además se realizó un cultivo mixto con estos aislados obteniendo como resultado diferencias en la densidad de la biopelícula y menos cambios en la actividad metabólica de la misma en los experimentos de variación de temperatura. A partir de los resultados podemos inferir que los consorcios bacterianos pueden favorecer la resistencia a variaciones ambientales en las biopelículas formadas por bacterias del género Bacillus.

PALABRAS CLAVES: Bacterias marinas, Bacillus, Biopelículas, Sedimentos.

\section{ABSTRACT}

$\mathrm{B}$ iofilm formation is an important process for marine bacterial communities because this mechanism favors adaptation to variations in environmental conditions. The objective of this study was to evaluate the biofilm formation of bacteria isolated from marine sediments under in vitro conditions. For this, biofilm quantification assays were performed using two methods, violet crystal and reduction of the XTT dye; In addition, the viability of the bacteria was evaluated by Live / Dead staining. Subsequently, the strains evaluated were identified using the 16S RNA marker. The results showed that the isolates belong to the genus Bacillus, all in different ranges were able to form films and strains B. safensis 64181 and Bacillus sp 64186 were selected which indicated greater production of this. Tests at different temperatures showed that for the strains selected the best temperature was $28^{\circ} \mathrm{C}$. In addition, a mixed culture was carried out with these isolates, resulting in differences in the density of the biofilm and less changes in its metabolic activity in temperature variation experiments. From the results we can infer that bacterial consortiums can favor resistance to environmental variations in biofilms formed by bacteria of the genus Bacillus.

KEYWORDS: Marine Bacteria, Bacillus, Biofilms, Sediments

DOI: 10.25268/bimc.invemar.2019.48.2.767

Publicado por INVEMAR

Este es un manuscrito de acceso abierto bajo la licencia CC

Reconocimiento-No Comercial-Compartir Igual 


\section{INTRODUCCIÓN}

Las bacterias existen en el medio acuático bajo dos formas o estados: a) pelágicas, de libre flotación, y b) bacterias en biopelículas, formando colonias sésiles (Nazar, 2007). Las biopelículas son comunidades de microorganismos que crecen incluidos en una matriz de exopolisacáridos y adheridos a una superficie inerte o a un tejido vivo. En principio la formación de una biopelícula se establece como parte de los procesos que se pueden presentar en el mecanismo quorum sensing (QS) (Díaz et al., 2011). Las bacterias mantienen una comunicación permanente entre ellas, dentro de los diferentes ambientes o microambientes donde permanecen y conviven. Los mecanismos de comunicación les permiten reconocer cuando se alcanza un umbral o nivel de presencia para desarrollar nuevas funciones, especialmente un comportamiento social, simbiótico y de permanente reconocimiento, útil para nuevas tareas (Nowak, 2009).

Las biopelículas naturales en muchos ambientes, se caracterizan a menudo por presentar alta densidad celular y alta diversidad de especies microbianas, que les permiten estrechas interacciones célula-célula dentro o entre las especies, dando lugar a inevitables interacciones intra e inter-especies, incluyendo la cooperación y la competencia (Kolenbrander et al., 2002). Estas interacciones pueden desempeñar papeles muy importantes en el mantenimiento de la homeostasis de microbios en una comunidad de la biopelícula (Kuramitsu et al., 2007).

En los procesos de colonización de sustratos limpios sumergidos que involucra la adhesión, desde moléculas disueltas, a bacterias, diatomeas e invertebrados, intervienen algunos factores que pueden favorecer $o$ dificultar la adhesión; por las fuerzas motrices, que pueden ser primarias o secundarias. La primera se relaciona con la abundancia relativa de cada tipo de molécula y microbiota en la columna de agua (Lau et al., 2002), mientras que las fuerzas motrices secundarias son las interacciones físicas, químicas y de comportamiento entre los incrustantes. Ejemplo de ello son las interacciones entre las bacterias asociadas a la superficie y las larvas de invertebrados que buscan asentarse (Rodriguez y Epifanio, 2000). Un caso puntual es el del poliqueto Hydroides elegans, que depende para su asentamiento de las bacterias, las cuales mediante la producción y posterior expulsión al medio de moléculas de comunicación contribuyen a que el poliqueto pueda

\section{INTRODUCTION}

Bacteria exist in the aquatic environment in two forms or states: a) pelagic, free floating, and b) bacteria in biofilms, forming sessile colonies (Nazar, 2007). Biofilms are communities of microorganisms that grow included in a matrix of exopolysaccharides and adhered to an inert surface or living tissue. In principle, the formation of a biofilm is established as part of the processes that can occur in the quorum sensing (QS) mechanism (Díaz et al., 2011). The bacteria maintain a permanent communication between them, within the different environments or microenvironments where they remain and coexist. Communication mechanisms allow them to recognize when a threshold or level of presence is reached to develop new functions, especially social, symbiotic and permanent recognition behavior, useful for new tasks (Nowak, 2009).

Natural biofilms in many environments are often characterized by high cell density and high diversity of microbial species, which allow close cell-cell interactions within or between species, leading to inevitable intra and interspecies interactions, including cooperation and competition (Kolenbrander et al., 2002). These interactions can play very important roles in maintaining microbial homeostasis in a biofilm community (Kuramitsu et al., 2007).

In the colonization processes of submerged clean substrates that involve adhesion, from dissolved molecules, to bacteria, diatoms and invertebrates, some factors are involved that can favor or hinder adhesion; by the driving forces, which can be primary or secondary. The first is related to the relative abundance of each type of molecule and microbiota in the water column (Lau et al., 2002), while the secondary driving forces are the physical, chemical and behavioral interactions between the encrustants. An example of this is the interactions between surface-associated bacteria and invertebrate larvae that seek to settle (Rodriguez and Epifanio, 2000). A punctual case is that of the Hydroides elegans polychaete, which depends on the bacteria for its settlement, which through the production and subsequent expulsion to the medium of communication molecules contribute to the polychaete being able to select the area to settle; the bacteria that have been related to this process are the Gram positive of the genera Bacillus, Brevibacterium, Micrococcus and Staphylococcus; and of the Gram negative of the genera Alteromonas, Pseudoalteromonas and Vibrio (Hadfield, 2011; Lau et al., 2002). The interaction between 
seleccionar el área para asentarse; a las bacterias que se les han relacionado con este proceso son las Gram positivas de los géneros Bacillus, Brevibacterium, Micrococcus y Staphylococcus, y las Gram negativas de los géneros Alteromonas, Pseudoalteromonas y Vibrio (Lau et al., 2002; Hadfield, 2011). La interacción entre bacterias y eucariotas bentónicos se ha demostrado incluso con evidencias paleontológicas que revelan una relación entre metazoos y biopelículas muy temprano en la evolución de estos; por lo tanto, los receptores a las señales bacterianas en las larvas de invertebrados son muy antiguos y posiblemente únicos (Hadfield, 2011).

Las bacterias juegan un rol importante en los ambientes marinos, incluyendo la participación en los ciclos biogeoquímicos del sulfuro, nitrógeno y carbono (Paerl y Pinckney, 1996; Hawley et al., 2017) supliendo de materiales y energía a niveles tróficos superiores (Azam et al., 1983; de Carvalho y Caramujo, 2012). Las especies del género Roseobacter son reconocidas como las principales colonizadoras de superficies en ambientes acuáticos debido a su rápida respuesta a la presencia de nutrientes en la etapa de acondicionamiento bioquímico del sustrato y la formación de biopelícula (Dang et al., 2008). De hecho, se ha encontrado que estas bacterias son los microbios más importantes en las superficies marinas para iniciar la colonización; estas células pueden determinar la estructura y función de las biopelículas maduras (Dang et al., 2008; Dang y Lovell, 2016). Colonizan superficies naturales, artificiales, aceleran la corrosión (Little et al., 2008), favorecen el biofouling (Cao et al., 2011) y pueden influir en la flotabilidad del plástico polietileno (Lobelle y Cunliffe, 2011). No obstante, Lee et al. (2018) sugieren que en el medio marino la composición de las comunidades bacterianas cambia a través del tiempo; las colonizadoras primarias se caracterizan por ser poco abundantes en él, pero de crecimiento rápido y las poblaciones varían de acuerdo con la superficie o nutrientes disponibles. Por estas razones es de suma importancia conocer las comunidades bacterianas asociadas a los sedimentos marinos y evaluar su capacidad de formación de biopelículas en condiciones de cultivo in vitro que permitan plantear hipótesis sobre su desarrollo en ambientes naturales.

\section{ÁREA DE ESTUDIO}

Punta de Betín se ubica en la costa Caribe colombiana y pertenece al área de Santa Marta, departamento bacteria and benthic eukaryotes has been demonstrated even with paleontological evidence that reveals a relationship between metazoans and biofilms very early in their evolution; therefore, bacterial signal receptors in invertebrate larvae are very old and possibly unique (Hadfield, 2011).

Bacteria play an important role in marine environments, including participation in the biogeochemical cycles of sulfur, nitrogen and carbon (Paerl and Pinckney, 1996; Hawley et al., 2017) supplying materials and energy at higher trophic levels (Azam et al., 1983; de Carvalho and Caramujo, 2012). Roseobacter species are recognized as the main surface colonizers in aquatic environments, due to their rapid response to the presence of nutrients in the biochemical conditioning stage of the substrate and biofilm formation (Dang et al., 2008). In fact, it has been found that these bacteria are the most important microbes on marine surfaces to initiate colonization; These cells can determine the structure and function of mature biofilms (Dang et al., 2008; Dang and Lovell, 2016). They colonize natural, artificial surfaces, accelerate corrosion (Little et al., 2008), favor biofouling (Cao et al., 2011), and can influence the buoyancy of polyethylene plastic (Lobelle and Cunliffe, 2011).

However, Lee et al. (2018) suggest that in the marine environment the composition of bacterial communities changes over time; the primary colonizers are characterized by being little abundant in it, but fast growing and populations vary according to the surface and available nutrients. For these reasons, it is very important to know the bacterial communities associated with marine sediments and evaluate their ability to form biofilms under in vitro culture conditions that allow to establish hypothesis about their development in natural environments.

\section{STUDY AREA}

Punta de Betín is located on the Colombian Caribbean coast and belongs to the Santa Marta area, department of Magdalena. It is a rocky peninsula of steep slopes, located north of Santa Marta bay, so it is directly affected by the discharge of fresh water (Manzanares river and submarine emissary) and the port (grains and coal dust) (Martínez and Acosta, 2016). The sampling station was located at the following coordinates $11^{\circ} 15^{\prime} 01.94$ 'N; 074 ${ }^{\circ} 13^{\prime} 10.73^{\prime} \mathrm{W}$, collecting samples at three depths 5, 10 and $15 \mathrm{~m}$ (Figure 1) 
del Magdalena. Es una península rocosa de pendientes escarpadas, localizada al norte de la bahía de Santa Marta, por lo que se ve directamente afectada por la descarga de aguas dulces (río Manzanares y emisario submarino) y el puerto (granos y polvillo de carbón) (Martínez y Acosta, 2016). La estación de muestreo se ubicó en las coordenadas $11^{\circ} 15^{\prime} 01,94$ ' $\mathrm{N}$ y $74^{\circ} 13^{\prime} 10,73^{\prime}$ 'W, recolectando muestras a tres profundidades: 5, 10 y $15 \mathrm{~m}$ (Figura 1).

\section{MATERIALS AND METHODS}

Sample collection.

The samples were collected in Punta Betín (Santa Marta Bay) with a Van Veen dredger of $14 \mathrm{~cm}$ in diameter with a sampling area of $0.08 \mathrm{~m} 2$ and autonomous diving, taking the surface sediment layer in triplicate in a range

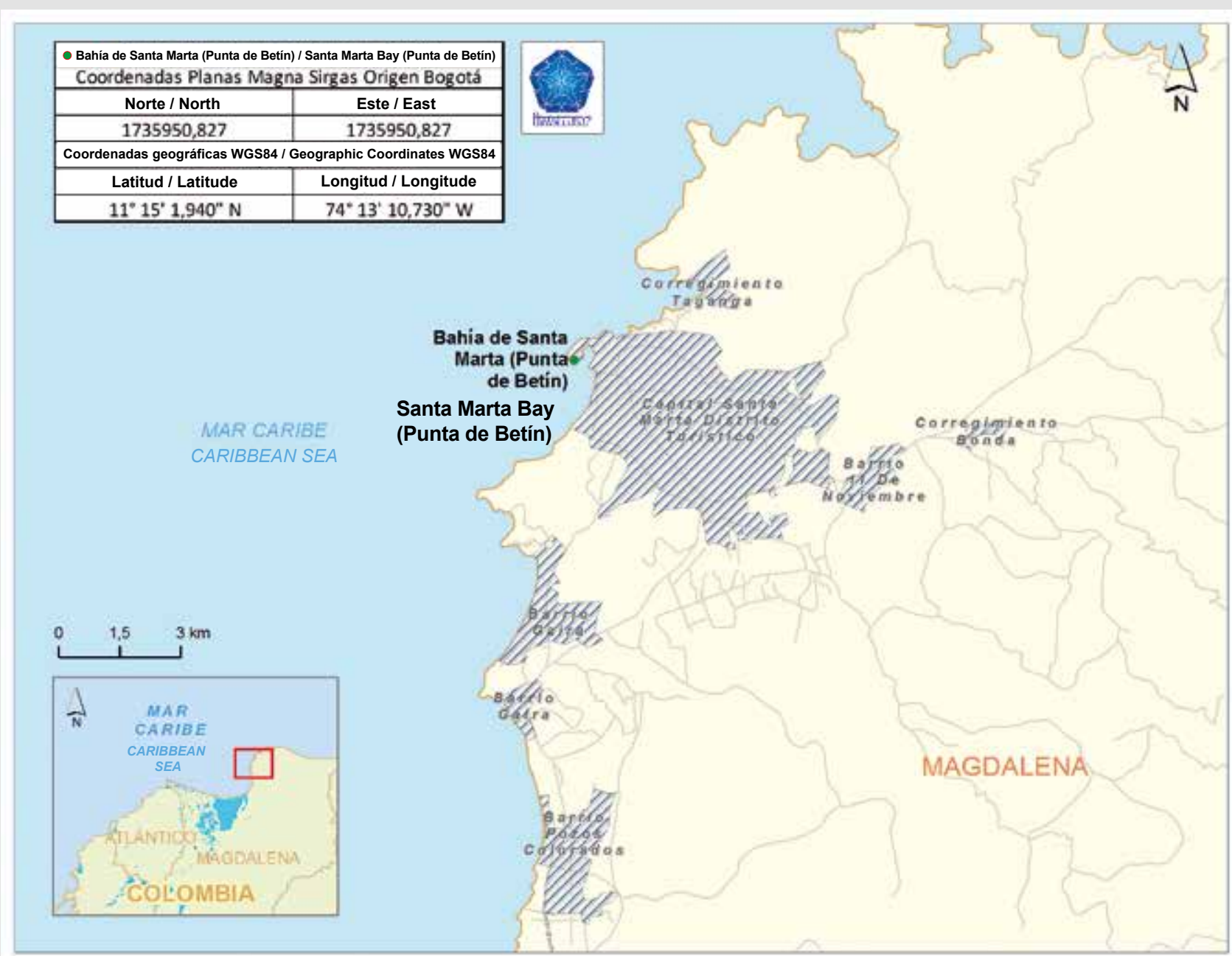

Figura 1. Ubicación de la localidad de Punta de Betín (punto verde) donde se recolectaron las muestras de sedimentos marinos.
Figure 1. Location of Punta de Betín (green point) where samples of marine sediments were collected.

\section{MATERIALES Y MÉTODOS}

Recolección de muestras.

Las muestras fueron recolectadas en Punta Betín (bahía de Santa Marta) con una draga Van Veen de $14 \mathrm{~cm}$ de diámetro con superficie de muestreo de $0,08 \mathrm{~m}^{2}$ y buceo autónomo, tomando la capa de sedimento superficial por of 5 to 15 meters deep. The collected samples were stored in sterile bottles lined with aluminum foil to protect them from light and stored in a plastic refrigerator with ice at approximately $4{ }^{\circ} \mathrm{C}$, to be transported to the marine natural products area of the Marine Bioprospecting Laboratory of Invemar-LabBIM for its processing. 
triplicado en un rango de 5 hasta $15 \mathrm{~m}$ de profundidad. Las muestras recolectadas fueron almacenadas en frascos estériles forrados con papel aluminio para protegerlos de la luz y almacenados en una nevera plástica con hielo aproximadamente a $4{ }^{\circ} \mathrm{C}$, para ser transportada al área de productos naturales marinos del Laboratorio de Bioprospección Marina del Invemar -LabBIM para su procesamiento.

\section{Crecimiento y aislamiento de bacterias marinas}

La obtención de bacterias cultivables a partir de las diferentes muestras, se realizó empleando medios sólidos con alta concentración de nutrientes, como el agar Tripticasa soja con $1 \%$ de $\mathrm{NaCl}$ (TSA-I), Agar Marino (AM), Agar ISP2 con $1 \% \mathrm{NaCl}$ y Agar Actinobacterias (Difco) enriquecido con sales (Raver, 2000). Se adicionaron $20 \mathrm{~g}$ de sedimento de la muestra en cajas de Petri estériles y se sometió a un tratamiento térmico en un horno a $50{ }^{\circ} \mathrm{C}$ por $60 \mathrm{~min}$, con el fin de eliminar la microbiota vegetal de la muestra (Rocha et al., 2013). A continuación, se realizaron diluciones seriadas $(1 / 10,1 / 100$ y $1 / 1000)$ en agua de peptona suplementada con agua de mar artificial estéril (1:1) y se sembraron en placas de agar incubándolas a $26^{\circ} \mathrm{C}$ por un período de $15-20$ días (León et al., 2007; Romero y Otero 2010; Torres et al., 2012).

\section{Conservación de las cepas}

Se aislaron las cepas del sedimento, que luego se conservaron en cultivos axénicos. Cada aislamiento se hizo en caldo nutritivo suplementado con $1 \%$ de $\mathrm{NaCl}$ y glicerol a $20 \%(\mathrm{~V} / \mathrm{V})$. Las cepas cultivadas fueron codificadas y almacenadas a una temperatura de $-80{ }^{\circ} \mathrm{C}$. A partir del concepto que la producción de antimicrobianos está regulada por mecanismos quorum sensing, en este trabajo solamente se evaluaron once cepas que mostraron actividad biológica contra microorganismos resistentes de interés clínico en ensayos realizados por el Laboratorio de Bioprospección Marina del Invemar. Finalmente, la codificación de estas se basó en la identificación molecular de las mismas. Las cepas fueron depositadas en el Museo de Historia Natural Marina de Colombia - Makuriwa del Invemar, el cual asignó los siguientes códigos para las cepas identificadas: 64093, 64094, 64095, 64096, 64097, 64100, 64101, 64181, 64186, 64170 y un aislado sin identificar 64156 .

\section{Growth and isolation of marine bacteria}

The collection of cultivable bacteria from the different samples was carried out using solid media with a high concentration of nutrients, such as Trypticase soy agar with $1 \% \mathrm{NaCl}$ (TSA-I), Marine Agar (AM), ISP2 Agar with $1 \% \mathrm{NaCl}$, and Actinobacteria Agar (Difco) enriched with salts (Raver, 2000). Twenty grams of sample sediment were added to sterile Petri dishes and then heat-treated in an oven at $50{ }^{\circ} \mathrm{C}$ for 60 minutes to remove the plant microbiota from the sample (Rocha et al., 2013). Serial dilutions (1/10, 1/100 and $1 / 1000)$ were then made in peptone water supplemented with sterile artificial seawater (1:1) and inoculated into agar plates incubating them at $26^{\circ} \mathrm{C}$ for a period of 15-20 days (León et al., 2007; Romero and Otero 2010; Torres et al., 2012).

\section{Conservation of strains}

The strains were isolated from the sediment in nutritive broth supplemented to $1 \% \mathrm{NaCl}$ and $20 \%$ glycerol $(\mathrm{V} / \mathrm{V})$, and then conserved in axenic cultures. The cultivated strains were coded and stored at a temperature of $-80{ }^{\circ} \mathrm{C}$. Based on the concept that antimicrobial production is regulated by quorum sensing mechanisms, in this work only eleven strains were evaluated that showed biological activity against resistant microorganisms of clinical interest in trials performed by INVEMAR's Marine Bioprospecting Laboratory. Finally, their coding was based on their molecular identification. The strains were deposited in the Museum of Marine Natural History of Colombia - Makuriwa of INVEMAR, which assigned the following codes for the identified strains: 64093, 64094, 64095, 64096, 64097, 64100, 64101, 64181, 64186, 64170 and an unidentified isolate 64156.

\section{Reactivation of strains}

The reactivation of the isolates evaluated in this work was carried out from a defrosting process that consisted of moving from $-80^{\circ} \mathrm{C}$ to $-20^{\circ} \mathrm{C}$ and leaving the strains for two hours at this temperature, then they were switched to $4^{\circ} \mathrm{C}$ and kept 1 hour at that temperature. Subsequently, $100 \mu 1$ (using the mass growth technique) were inoculated in Petri dishes with TSA agar at $28^{\circ} \mathrm{C}$ for 48 hours; They were finally kept at $4^{\circ} \mathrm{C}$ for use during this study.

\section{Genetic identification}

The genetic identification of the eleven strains was realize on a culture in TSA agar incubated at $28^{\circ} \mathrm{C}$ for 48 hours. 


\section{Reactivación de las cepas}

La reactivación de los aislados evaluados en este trabajo se llevó a cabo a partir de un proceso de descongelamiento que consistió en pasar de $-80{ }^{\circ} \mathrm{C}$ a -20 ${ }^{\circ} \mathrm{C}$ y dejar las cepas durante dos horas en esta temperatura, luego se pasaron a $4{ }^{\circ} \mathrm{C}$ y se mantuvieron una hora a esa temperatura. Posteriormente, se inocularon $100 \mu \mathrm{l}$ (usando la técnica de crecimiento masivo) en cajas Petri con agar TSA a $28^{\circ} \mathrm{C}$ durante $48 \mathrm{~h}$; finalmente se mantuvieron a $4{ }^{\circ} \mathrm{C}$ para su uso durante este estudio.

\section{Identificación genética}

La identificación genética de las once cepas partió de un cultivo en agar TSA incubado a $28^{\circ} \mathrm{C}$ durante $48 \mathrm{~h}$.

\section{Extracción del ADN}

La extracción del ADN se realizó usando el kit PureLink Genomic DNA de Invitrogen. Se realizó elución en un volumen final de $50 \mu \mathrm{l}$. Al finalizar el proceso de extracción se realizó por espectrofotometría a longitudes de onda de 260/280 nm en un equipo Nanodrop (Thermo Fisher Scientific).

\section{Amplificación del marcador ARN 16S}

El ADN obtenido crudo se empleó como plantilla en la amplificación de la región $16 \mathrm{~S}$ mediante reacción en cadena de la polimerasa (PCR) (Dashti et al., 2009; Sowmya et al., 2012). El gen $16 \mathrm{~S}$ se amplificó empleando los iniciadores universales 27F (5' -AGA GTT TGA TCM TGG CTC AG-3') y 1492R (5'-GGT TAC CTT GTT ACG ACT T-3') (Weisburg et al., 1991) que amplifican un fragmento de 1500 pares de bases (pb) aproximadamente.

Las condiciones de la PCR fueron: desnaturalización inicial del $\mathrm{ADN}$ a $94^{\circ} \mathrm{C}$ durante $3 \mathrm{~min}$, 35 ciclos de amplificación, desnaturalización a $94^{\circ} \mathrm{C}$ durante $30 \mathrm{~s}$, recocido del cebador a $50^{\circ} \mathrm{C}$ durante $30 \mathrm{~s}$, extensión del cebador a $72^{\circ} \mathrm{C}$ durante $2 \mathrm{~min}$, seguido de una extensión final a $72^{\circ} \mathrm{C}$ durante $8 \mathrm{~min}$ (termociclador T-100 Bio-Rad). Los productos de PCR se migraron en gel de agarosa al $1 \%(\mathrm{p} / \mathrm{v})$ a $100 \mathrm{~V}$ durante $80 \mathrm{~min}$, tampón TBE $1 \mathrm{X}$ y 1 ll de tampón de carga EZ-vision (AMRESCO). Los resultados se visualizaron por exposición a la luz ultravioleta y se fotografiaron con un sistema de captura digital (ENDUROTM GDS - LABNET). Adicionalmente, la identidad de algunos aislados del género Bacillus fue complementada a nivel de especie mediante la amplificación del gen codificante para la chaperonina groEL empleando los

\section{DNA extraction}

DNA extraction was performed using the Invitrogen PureLink Genomic DNA kit. Elution was performed in a final volume of $50 \mu \mathrm{l}$. At the end of the extraction process, it was performed by spectrophotometry at wavelengths of 260/280 $\mathrm{nm}$ in a Nanodrop (Thermo Fisher Scientific) equipment.

Amplification of the RNA 16S marker

The crude obtained DNA was used as a template in the amplification of the $16 \mathrm{~S}$ region by polymerase chain reaction (PCR) (Dashti et al., 2009; Sowmya et al., 2012). The $16 \mathrm{~S}$ gene was amplified using universal primers $27 \mathrm{~F}$ (5'-AGA GTT TGA TCM TGG CTC AG-3 ') and 1492R (5'-GGT TAC CTT GTT ACG ACT T-3') (Weisburg et al., 1991), which amplify a fragment of approximately 1500 base pairs (bp).

The PCR conditions were: initial denaturation of the DNA at $94^{\circ} \mathrm{C}$ for $3 \mathrm{~min}, 35$ cycles of amplification, denaturation at $94^{\circ} \mathrm{C}$ for $30 \mathrm{~S}$, annealing of the primer at $50^{\circ} \mathrm{C}$ for $30 \mathrm{~S}$, extension of the primer at $72^{\circ} \mathrm{C}$ for $2 \mathrm{~min}$, followed by a final extension at $72^{\circ} \mathrm{C}$ for $8 \mathrm{~min}$ (T-100 BioRad thermal cycler). The PCR products were migrated in $1 \%$ agarose gel $(\mathrm{w} / \mathrm{v}$ ) at $100 \mathrm{~V}$ for 80 minutes, $1 \mathrm{X}$ TBE buffer and $11 \mathrm{ll}$ of EZ-vision loading buffer (AMRESCO). The results were visualized by exposure to ultraviolet light and photographed with a digital capture system (ENDUROTM GDS - LABNET). Additionally, the identity of some isolates of the genus Bacillus was complemented at the species level by amplification of the coding gene for chaperonin groEL using initiators 550F (5'-GAGCTTGAAGTKGTTGAAGG-3 ') and 1497R (5'-TGAGCGTGTWACTTTTGTWG-3') (Rooney et al., 2009).

\section{RNA 16S marker sequencing}

The amplification product was subjected to sequencing reaction by the Sanger / capillary method and reading both chains to ensure the reliability of sequencing. This was done at the facilities of Corpogen, a corporation in Bogotá.

Assembly and Classification based on the 16S marker

The sequences obtained were purified from the ends with low quality bases and assembled with the eBioX version 1.5.1 program. The final sequence was analyzed by comparison with the sequences deposited in the BLAST server database of the National Center for Biotechnology Information (NCBI) and the rRNA Database Project (RDP II). 
iniciadores 550F (5'-GAGCTTGAAGTKGTTGAAGG-3')

y 1497R (5'-TGAGCGTGTWACTTTTGTWG-3')

(Rooney et al., 2009).

\section{Secuenciamiento del marcador ARN 16S}

El producto de amplificación se sometió a reacción de secuenciamiento por el método de Sanger/capilar y leyendo ambas cadenas para asegurar la fiabilidad de la secuenciación. Esto fue realizado en las instalaciones de la corporación Corpogen en Bogotá e instalaciones del Centro Nacional de Secuenciación Genómica de la Universidad de Antioquia en Medellín.

Ensamblaje y Clasificación basado en el marcador 16S

Las secuencias obtenidas fueron depuradas de los extremos con bases de baja calidad y ensambladas con el programa eBioX versión 1.5.1. La secuencia final fue analizada mediante comparación con las secuencias depositadas en la base de datos del servidor BLAST del National Center for Biotechnology Information (NCBI) y el rRNA Database Project (RDP II).

Las secuencias codificantes para el ARNr 16S fueron alineadas con el programa SINA (Silva Incremental Aligner v1.2.11), el cual usa una combinación entre las secuencias de los k-mer y la alineación de orden parcial (POA) con el fin de mantener una alta precisión (Pruesse et al., 2012). La identidad de las secuencias fue comparada con las secuencias de referencia alojadas por SILVA RDP, Greengenes and SILVA, empleando el método del ancestro común más bajo (ACB) y buscando cinco de las secuencias más cercanas con una identidad mínima de 0,97.

\section{Análisis Filogenético}

El análisis filogenético se llevó a cabo inicialmente con un análisis de distancias de las diez secuencias obtenidas durante el proceso de secuenciación y realizando una búsqueda en las bases de datos con secuencias reportadas del género Bacillus para el marcador ARN 16S. Para la construcción del árbol se usó el software MEGA 7 con el método de máxima verosimilitud con 1000 réplicas de Bootstrap, siguiendo el modelo de evolución Hasegawa, Kishino y Yano (1985).

Inducción a la formación de biopelículas y diseño experimental

Para la inducción a la formación de biopelículas en las once cepas estudiadas, se realizó un preinóculo de cada una de las cepas en caldo tripticasa de soya (TSB), y en frascos
The coding sequences for the 16S rRNA were aligned with the SINA program (SILVA Incremental Aligner v1.2.11), which uses a combination between the $\mathrm{k}$-mer sequences and the partial order alignment (POA) in order to maintain a high precision (Pruesse et al., 2012). The sequence identity was compared with the reference sequences hosted by SILVA RDP, Greengenes and SILVA, using the lowest common ancestor method (ACB) and looking for five of the closest sequences with a minimum identity of 0.97 .

\section{Phylogenetic analysis}

The phylogenetic analysis was initially carried out with a distance analysis of the ten sequences obtained during the sequencing process and performing a search in the databases with reported sequences of the Bacillus genus for the 16S RNA marker. For the construction of the tree, the MEGA 7 software was used with the maximum likelihood method with 1000 Bootstrap replicas, following the Hasegawa, Kishino and Yano (1985) evolution model.

Induction of biofilm formation and experimental design

For the induction to the formation of biofilms in the eleven strains studied, a pre-circle of each of the strains in trypticase soy broth (TSB), and in microbiological bottles was made, adding $5 \mathrm{ml}$ of the culture medium plus $200 \mu \mathrm{l}$ of the strain and left under stirring for $24 \mathrm{~h}$ at $28^{\circ}$ C. Subsequently, the absorbance at a $600 \mathrm{~nm}$ wavelength was measured with a Multiskan Go (Thermo Scientific) spectrophotometer, to confirm that the absorbance was not greater than 0.2 in order to have all strains in the same concentration to perform the test.

The biofilm formation was carried out in 96-well flat bottom plates and in each well $100 \mu 1$ of the strain and $100 \mu 1$ of fresh TSB medium was added, incubating all strains initially at $28^{\circ} \mathrm{C}$ and under static conditions, to induce the formation of the biofilm for 24, 48, 72 hours. Subsequently, two strains with greater biofilm formation (64181 and 64186) were selected to perform tests at different temperatures (26, 28 and $30^{\circ} \mathrm{C}$ ) for 48 hours. As a negative control, a strain of Staphylococcus aureus ATCC 43300 was used, which was grown under the same conditions as the strains studied. Five repetitions were performed for each strain, including the negative control, and each quantification experiment was replicated three times. All this for both methods (Violet Crystal, XTT). In the graphs presented, the last two digits of the five utilized are used as the code of each strain. 
microbiológicos, adicionando $5 \mathrm{ml}$ del medio de cultivo más $200 \mu 1$ de la cepa y se dejaron en agitación durante 24 h a 28 ${ }^{\circ} \mathrm{C}$. Posteriormente, se midió la absorbancia a una longitud de onda $600 \mathrm{~nm}$ con un espectrofotómetro Multiskan Go (Thermo Scientific), para confirmar que la absorbancia no fuera superior a 0,2 con el propósito de tener todas las cepas en la misma concentración para realizar el ensayo.

La formación de las biopelículas se llevó a cabo en placas de 96 pozos de fondo plano y en cada pocillo se adicionaron $100 \mu 1$ de la cepa y $100 \mu 1$ de medio TSB fresco, incubandotodas las cepas inicialmente a $28^{\circ} \mathrm{Cy}$ en condiciones estáticas, para inducir a la formación de la biopelícula durante 24, 48, 72 h. Posteriormente, se seleccionaron dos cepas con mayor formación de biopelícula (64181 y 64186) para realizar ensayos a diferentes temperaturas $\left(26,28\right.$ y $\left.30^{\circ} \mathrm{C}\right)$ por $48 \mathrm{~h}$. Como control negativo se utilizó una cepa de Staphylococcus aureus ATCC 43300, la cual se puso a crecer en las mismas condiciones que las cepas estudiadas. Por cada cepa se realizaron cinco repeticiones, incluyendo el control negativo, y cada experimento de cuantificación se replicó tres veces. Todo esto para ambos métodos (Cristal violeta, XTT).

En las gráficas que se presentan se usa como código de cada cepa los dos últimos dígitos de los cinco utilizados.

\section{Tinción con cristal violeta}

La cuantificación de la formación de biopelículas a los ensayos de 24, 48 y 72 h, se llevó a cabo con la tinción con cristal violeta; para ello se extrajo el medio de cultivo de los pozos y se les realizaron tres lavados con $200 \mu 1$ de PBS 1X; después se realizó un lavado con agua estéril y se tiñó con $200 \mu \mathrm{l}$ de cristal violeta a una concentración de $0,2 \%$; se esperó 15 minutos y se extrajo el colorante para realizar nuevamente dos lavados con $200 \mu 1$ de agua estéril, dejando secar al aire libre; a continuación se añadió una solución de ácido acético $10 \%$, etanol $50 \%$ y agua $40 \%$ $(\mathrm{v} / \mathrm{v} / \mathrm{v})$ para diluir el cristal violeta y finalmente se midió la absorbancia a una longitud de onda $540 \mathrm{~nm}$ a los ensayos de 24,48 y $72 \mathrm{~h}$.

El análisis estadístico realizado a los datos fue la media, desviación estándar y se aplicó la fórmula de densidad óptica (OD) del control para clasificar las cepas de acuerdo con la formación de la biopelícula; esto se realizó con los resultados del ensayo a las $48 \mathrm{~h}$. Las categorías seleccionadas fueron no productores, productores débiles, productores medios y productores muy fuertes (Tabla 1) (Stepanovic et al., 2000).

\section{Staining with violet crystal}

The quantification of biofilm formation at the 24, 48 and 72 hour assays was carried out with violet crystal staining; for this, the culture medium was extracted from the wells and three washes were carried out with $200 \mu \mathrm{l}$ of $1 \mathrm{X}$ PBS; then a sterile water wash was performed and stained with $200 \mu 1$ of violet crystal at a concentration of $0.2 \% ; 15$ minutes were expected and the dye was extracted to perform again two washes with $200 \mu 1$ of sterile water, allowing to dry in the open air; then a solution of $10 \%$ acetic acid, $50 \%$ ethanol and $40 \%$ water (v/ v / v) was added to dilute the violet crystal and finally the absorbance at a wavelength 540 $\mathrm{nm}$ was measured to the 24 tests, 48 and $72 \mathrm{~h}$.

The statistical analysis performed on the data was the mean, standard deviation and the optical density (OD) formula of the control was applied to classify the strains according to the biofilm formation; This was done with the test results at $48 \mathrm{~h}$. The selected categories were nonproducers, weak producers, medium producers, and very strong producers (Table 1) (Stepanovic et al., 2000).

\section{Staining and quantification of metabolic activity} Reagent preparation

For the quantification of the biofilm metabolic activity, the reduction of the tetrazolium chloride-XTT dye (Sigma-Aldrich) was used as a method by cellular respiration. For this, a mixture of XTT and menadione was prepared. The XTT was prepared at $1 \mathrm{mg} / \mathrm{ml}$ and dissolved in $1 \mathrm{X}$ PBS then filtered through a $0.22 \mu \mathrm{m}$ filter. Menadione was prepared at a concentration of $400 \mathrm{mM}$ and dissolved in acetone for subsequent filtration at $0.22 \mu \mathrm{m}$. The XTT / Menadiona mixture was performed at a 5: 1 ratio.

XTT staining was initiated by washing the biofilms with $200 \mu 1$ of 1X PBS (3 washes) to eliminate plankton bacteria that might be in the wells; $200 \mu 1$ of PBS and 12 $\mu 1$ of XTT / Menadione reagent were then added and the microplate was incubated at $30^{\circ} \mathrm{C}$ for two hours, without being exposed to light and absorbance was measured at 490 $\mathrm{nm}$. Dye reduction is a measure of metabolic activity.

\section{Cell Viability - Live/Dead Staining}

Biofilm formation assays were performed on glass coverslips for $24 \mathrm{~h}$ for strains 64181 and 64186 and for the mixed assay. To carry out the above, the sterile coverslips were placed in Petri dishes with $5 \mathrm{ml}$ of fresh culture and $20 \mu 1$ of the medium with the strains, incubating them at $28^{\circ} \mathrm{C}$ for the development of the biofilm. After time, the coverslips were washed with $1 \mathrm{X}$ PBS and stained with the 
Tabla 1. Parámetros para clasificación de las cepas según la adherencia a superficies.
Table 1. Parameters for classification of strains according to adherence to surfaces.

\begin{tabular}{|c|c|c|}
\hline Clasificación & Fórmula & Rango \\
\hline Classification & Formula & Range \\
\hline No productores / Non-producers & $\begin{array}{c}\mathrm{OD}_{\mathrm{c}}+3 \text { (Desviación estándar / Standard } \\
\text { deviation) }\end{array}$ & ODcepa $<\mathrm{OD}_{\mathrm{c}}$ \\
\hline Productores débiles / Weak producers & $\begin{array}{c}2\left(\mathrm{OD}_{\mathrm{c}}+3(\text { Desviación estándar / Standard }\right. \\
\text { deviation }))\end{array}$ & $\mathrm{OD}_{\mathrm{c}}<$ ODcepa $\leq 2 \mathrm{OD}_{\mathrm{c}}$ \\
\hline Productores medios / Mid-level producers & $\begin{array}{c}4\left(\mathrm{OD}_{\mathrm{c}}+3 \text { (Desviación estándar / Standard }\right. \\
\text { deviation) })\end{array}$ & $2 \mathrm{OD}_{\mathrm{c}}<\mathrm{ODcepa} \leq 4 \mathrm{OD}_{\mathrm{c}}$ \\
\hline Productores muy fuertes / Very strong producers & 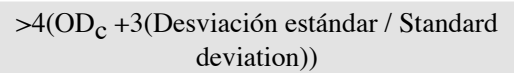 & $>4 \mathrm{OD}_{\mathrm{c}}$ \\
\hline
\end{tabular}

Tinción y cuantificación de la actividad metabólica

\section{Preparación de los reactivos}

Para la cuantificación de la actividad metabólica de las biopelículas se usó como método la reducción del colorante cloruro de tetrazolio - XTT (Sigma-Aldrich) mediante respiración celular. Para ello se preparó una mezcla de XTT y menadiona. El XTT se preparó a $1 \mathrm{mg} / \mathrm{ml}$ y se disolvió en PBS 1X, luego se filtró mediante un filtro de 0,22 $\mu \mathrm{m}$. La menadiona se preparó a una concentración de 400 $\mathrm{mM}$ y se disolvió en acetona para filtrarse posteriormente a $0,22 \mu \mathrm{m}$. La mezcla XTT/Menadiona se realizó a una proporción 5:1.

La tinción XTT se inició con el lavado de las biopelículas con $200 \mu 1$ de PBS $1 \mathrm{X}$ (tres lavados) para eliminar bacterias planctónicas que pudieran estar en los pozos; luego se agregaron $200 \mu 1$ de PBS y $12 \mu 1$ de reactivo XTT/Menadiona y se incubó la microplaca a $30{ }^{\circ} \mathrm{C}$ durante dos $\mathrm{h}$, sin exponerse a la luz y se midió la absorbancia a $490 \mathrm{~nm}$. La reducción del colorante es una medida de la actividad metabólica.

\section{Viabilidad celular - Tinción Live/Dead}

Se realizaron ensayos de formación de biopelículas en cubreobjetos de vidrio durante $24 \mathrm{~h}$ para las cepas 64181 y 64186 y para el ensayo mixto. Para llevar a cabo lo anterior, los cubreobjetos estériles se colocaron en placas de Petri con $5 \mathrm{ml}$ de cultivo fresco y $20 \mu 1$ del medio con las cepas, incubándolos a $28{ }^{\circ} \mathrm{C}$ para el desarrollo de la biopelícula. Transcurrido el tiempo, los cubreobjetos fueron lavados con PBS 1X y se tiñeron con el sistema LIVE/DEAD® Viability Kit (Invitrogen), dejándolos en incubación durante 15 a 20 min a temperatura ambiente. La formación de las biopelículas se visualizó mediante un microscopio de epifluorescencia, lo que permitió reconocer mediante la tinción Live/Dead las células que estaban vivas (verde - amarillo) y las células muertas (rojas).
LIVE / DEAD® Viability Kit (Invitrogen) system, leaving them in incubation for 15 to $20 \mathrm{~min}$ at room temperature. The formation of the biofilms was visualized by means of an epifluorescence microscope, which allowed to recognize by means of the Live / Dead staining the cells that were alive (green - yellow) and the dead cells (red).

\section{Statistical analysis}

The statistical analysis of the data was first performed with the Excel software to make the graphs of averages and standard deviations for each experiment. Subsequently the inferential analysis of the data was done with the R software; First, the data of each experiment were tested for normality and homogeneity of variances; then, according to these results, in order to compare the means between treatments (strains, times, temperatures), ANOVA analysis of variance was performed in the case of parametric data and Kruskal Wallis for non-parametric data; in each case, tests of multiple comparisons Tukey and Nemenyi were performed respectively with a $\mathrm{p} \leq 0.05$.

\section{RESULTS}

\section{Molecular identification}

Phylogenetic analysis from the sequences of the 16S RNA gene allowed them to be classified within the genus Bacillus; however, it was only possible to identify strain 64181. Until this species, the groEL marker was used (Rooney et al., 2009), a fragment that codes for a protein that allows to tolerate thermal changes in Bacillus species. This marker indicated that said strain corresponds to the species Bacillus safensis with a $100 \%$ identity percentage (Figure 3).

The other strains analyzed were grouped according to the maximum likelihood tree in the Bacillus subtilis, Bacillus cereus and Bacillus pumilus groups. For example, 


\section{Análisis estadístico}

El análisis estadístico de los datos se efectuó primero con el software Excel para realizar las gráficas de promedios y desviaciones estándar para cada experimento. Posteriormente el análisis inferencial de los datos se hizo con el software R; primero, a los datos de cada experimento se les realizó una prueba de normalidad y homogeneidad de varianzas; luego, de acuerdo con estos resultados, para comparar las medias entre tratamientos (cepas, tiempos, temperaturas) se hicieron análisis de varianza ANOVA en el caso de los datos paramétricos y Kruskal Wallis para los no paramétricos; en cada caso se realizaron pruebas de comparaciones múltiples Tukey y Nemenyi respectivamente con un $p \leq 0,05$.

\section{RESULTADOS}

\section{Identificación molecular}

El análisis filogenético a partir de las secuencias del gen 16S ARN permitió clasificarlas dentro del género Bacillus; sin embargo solo fue posible identificar hasta especie la cepa 64181. Para esto se usó el marcador groEL (Rooney et al., 2009), fragmento que codifica para una proteína que permite tolerar cambios térmicos en especies de Bacillus. Este marcador indicó que dicha cepa corresponde a la especie Bacillus safensis con un porcentaje de identidad del 100\% (Figura 3).

Las otras cepas analizadas se agruparon según el árbol de máxima verosimilitud en los grupos de Bacillus subtilis, Bacillus cereus y Bacillus pumilus. Por ejemplo, la cepa 64097 se ubicó cercana a las secuencias de referencia del grupo Bacillus subtilis, formando un grupo hermano con valor de bootstrap de 83; las cepas 64101, 64170, por su parte, formaron grupos hermanos con las secuencias de referencia del grupo Bacillus cereus, ambas con Bacillus thuringiensis strain IAM12077 (NR043403.1) con valor de bootstrap de 92 y la cepa 64096 con Bacillus cibi strain SH43 (KM248377.1) mostrando un bootstrap de 89. Los aislados restantes se ubicaron en el grupo Bacillus pumilus, el cual se dividió en dos clados uno con bootstrap de 97 y el otro con 83 (Figura 2).

\section{Inducción a la formación de biopelículas}

\section{Ensayo general con tinción de cristal violeta}

Los ensayos para la inducción a la formación de biopelícula, realizados para todas las cepas a las 24 y 48 $\mathrm{h}$ mostraron que en condiciones estáticas y a temperatura strain 64097 was located close to the reference sequences of the Bacillus subtilis group, forming a brother group with bootstrap value of 83, while strains 64101, 64170 formed sibling groups with the reference sequences of the Bacillus cereus group, both with Bacillus thuringiensis strain IAM12077 (NR043403.1) with bootstrap value of 92 and strain 64096 with Bacillus cibi strain SH43 (KM248377.1) showing a bootstrap of 89 . The remaining isolates were located in the Bacillus pumilus group, which It was divided into two clades, one with bootstrap of 97 and the other with 83 (Figure 2).

\section{Induction of biofilm formation}

\section{General test with violet crystal staining}

The tests for the induction to biofilm formation, performed for all strains at 24 and 48 hours showed that under static conditions and at a temperature of $28^{\circ} \mathrm{C}$, bacilli isolated from marine sediments are mostly forming different biofilms, standing out B. safensis 64181 and Bacillus sp 64186 as the ones with the highest adherence and Bacillus sp 64093, Bacillus sp 64100 and 64156 were excepted, which showed no adherence (Table 2). This classification was made from two cuts on the absorbance values obtained from the results of the violet crystal test at 48 hours, at which time the greater formation of biofilm by the bacteria was evidenced; As a negative control, $S$. aureus bacteria was used because it is a bacterium with biofilm formation capacity that is less than $37{ }^{\circ} \mathrm{C}$ difficult to perform this process.

It is important to note that the optical density (O.D) of the isolates was compared with that of the negative control and was considered biofilm forming when this absorbance was greater than 0.4 (Figure 4).

Regarding the comparison of the behavior of all strains between 24 and $48 \mathrm{~h}$ at $28{ }^{\circ} \mathrm{C}$ and under static conditions, most strains increased the biomass from 24 to $48 \mathrm{~h}$, with the exception of strains 64156 and 64170 (Figure 4). The significant differences shown in the following graph correspond to strains 64097,64181 and 64186 with respect to the negative control $(-)(\mathrm{p} \leq 0.05)$ at $48 \mathrm{~h}$.

\section{Biofilm formation strains 64181 and 64186}

According to the results, B. safensis 64181 and Bacillus sp 64186, were the ones with the highest biofilm formation (Table 2 and Figure 4), therefore they were quantified separately and together (mixed culture) at 24, 48 


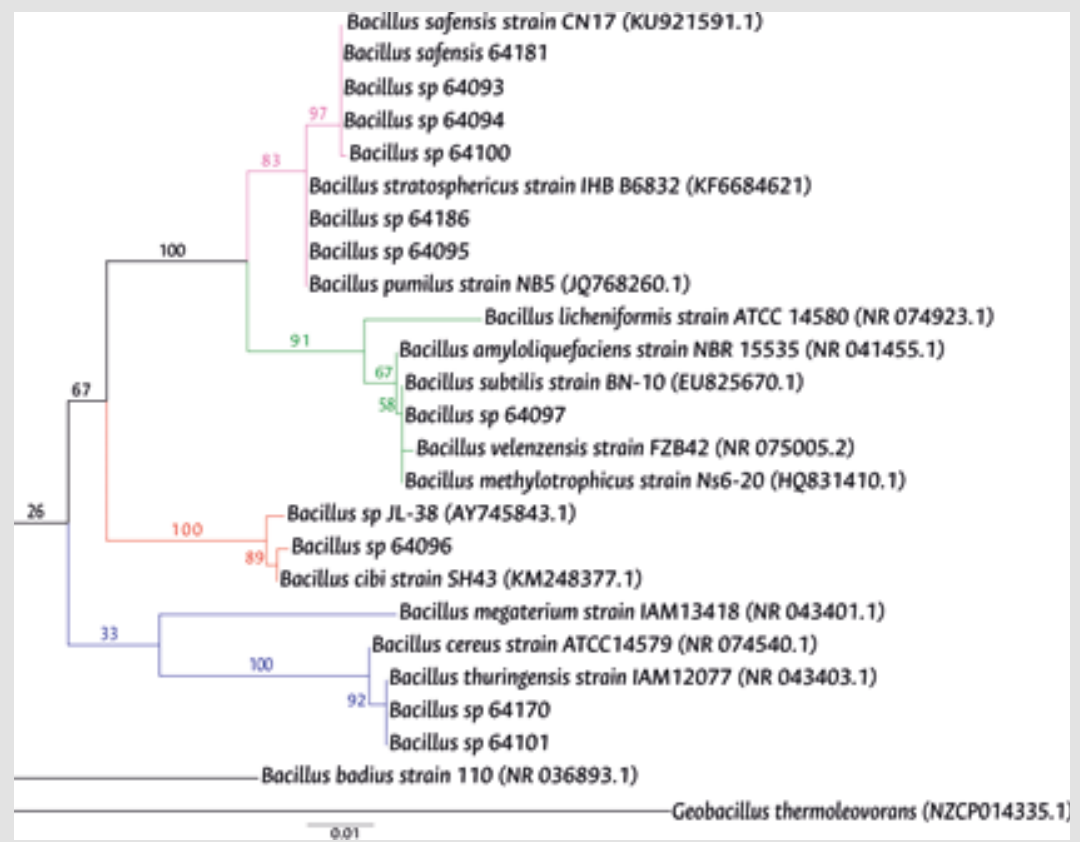

Figura 2. Árbol de máxima verosimilitud representando la relación filogenética de las cepas estudiadas basado en el gen 16S ARN. Los valores de bootstrap se muestran en porcentaje. En paréntesis se indica el código de acceso en el GenBank. Ramas en azul representan el grupo de Bacillus cereus, las rojas el grupo de Bacillus cibi, las verdes el grupo de Bacillus subtilis, las rosadas el grupo de Bacillus pumilus.
Figure 2. Maximum likelihood tree representing the phylogenetic relationship of the strains studied based on the 16S RNA gene. Bootstrap values are shown as a percentages. The access code in GenBank is indicated in parentheses. Blue branches represent the Bacillus cereus group, red branches represent the Bacillus cibi group, green branches represent the Bacillus subtilis group, pink branches represent the Bacillus pumilus group.
Figura 3. Árbol de Neighbor joining representando la relación filogenética de la especie Bacillus safensis cepa 64181 (punto rojo) basada en el gen groEL. Los valores de bootstrap se muestran en porcentaje.
Figure 3. Neighbor joining tree representing the phylogenetic relationship of the species Bacillus safensis strain 64181 (red dot) based on the groEL gene. Bootstrap values are shown in percentages. 
de $28{ }^{\circ} \mathrm{C}$, los bacilos aislados de sedimentos marinos en su mayoría son formadores en diferente medida de biopelícula, destacándose B. safensis 64181 y Bacillus sp 64186 como las de mayor adherencia, exceptuando Bacillus sp 64093, Bacillus sp 64100 y 64156, que no mostraron adherencia (Tabla 2). Esta clasificación se realizó a partir de dos cortes sobre los valores de absorbancia obtenidos de los resultados del ensayo de cristal violeta a las $48 \mathrm{~h}$, tiempo en el que se evidenció la mayor formación de biopelícula por parte de las bacterias; como control negativo se usó la bacteria $S$. aureus por ser una bacteria con capacidad de formación de biopelícula que a menos de $37^{\circ} \mathrm{C}$ se le dificulta realizar este proceso.

Tabla 2. Clasificación según la producción de biopelículas de las cepas a $28^{\circ} \mathrm{C}$ y a las 48 horas.

\begin{tabular}{|c|c|c|c|}
\hline $\begin{array}{c}\text { No adherente } \\
\text { Non adherent }\end{array}$ & $\begin{array}{c}\text { Débilmente adherente } \\
\text { Weakly adherent }\end{array}$ & $\begin{array}{c}\text { Moderadamente adherente } \\
\text { Moderately adherent }\end{array}$ & $\begin{array}{c}\text { Fuertemente adherente } \\
\text { Strongly adherent }\end{array}$ \\
\hline Bacillus $\mathrm{sp} 64093$ & Bacillus $\mathrm{sp} 64170$ & Bacillus sp 64094 & Bacillus safensis 64181 \\
64156 & Bacillus $\mathrm{sp} 64101$ & Bacillus sp 64095 & Bacillus sp 64186 \\
\hline Bacillus $\mathrm{sp} 64100$ & & Bacillus sp 64096 & \\
& & Bacillus $\mathrm{sp} 64097$ & \\
\hline
\end{tabular}

Es importante resaltar que fue comparada la densidad óptica (O.D) de los aislados con la del control negativo y se consideró formadora de biopelícula cuando esta absorbancia fue superior a 0,4 (Figura 4).

En cuanto a la comparación del comportamiento todas las cepas entre las 24 y $48 \mathrm{~h}$ a $28^{\circ} \mathrm{C}$ y en condiciones estáticas, la mayoría de las cepas aumentaron la biomasa de las 24 a las $48 \mathrm{~h}$, a excepción de las cepas 64156 y 64170 (Figura 4). Las diferencias significativas que se muestran en la siguiente gráfica corresponden a las cepas 64097,64181 y 64186 respecto al control negativo $(-)(p$ $\leq 0,05)$ a las $48 \mathrm{~h}$.

\section{Formación de biopelículas cepas 64181 y 64186}

De acuerdo con los resultados, B. safensis $64181 \mathrm{y}$ Bacillus sp 64186 fueron las de mayor formación de biopelículas (Tabla 2 y Figura 4), por lo tanto se procedió a su cuantificación por separado y juntas (mixto) a las 24, 48 y $72 \mathrm{~h}$; luego de este tiempo se presentaron inconvenientes para la lectura de la absorbancia debido a la alta formación de biomasa, lo que hizo difícil obtener la densidad óptica (O.D.) del ensayo. En la Figura 5 se muestra que la mayor formación de biopelícula se da a las $48 \mathrm{~h}$ en condiciones estáticas, alcanzando un O.D. and 72 hours, after this time thre were inconveniences for absorbance reading due to the high biomass formation, which made it difficult to obtain the optical density (OD) of the test. For the mixed biofilm assay, it was observed that biofilm formation was inferior to that shown by the treatment of each individual strain, although the fact that growth conditions were the same for all treatments (Figure 5). In relation to the experiments carried out at different temperatures for $B$. safensis 64181, Bacillus sp 64186 and joints (mixed culture) (Figure 6), it was determined that at $26^{\circ} \mathrm{C}$ and $30^{\circ} \mathrm{C}$ there are significant differences $(p \leq 0.05)$ in biofilm formation with respect to the temperature of $28^{\circ} \mathrm{C}$.

Table 2. Classification according to biofilm production of strains at $28{ }^{\circ} \mathrm{C}$ and at 48 hours.

\section{General assay for metabolic activity with XTT}

In order to determine the metabolic activity of the biofilm, XTT assays were also performed on all strains and the negative control (-), observing that all have a metabolic activity above 0.6 and in some increases from 24 to 48 $\mathrm{h}$, it is highlighted again that the strains with the highest activity were 64097, 64181 and 64186 (Figure 7). Again, trials with each strain showed that the greatest metabolic activity occurs at 48 hours, with the activity lasting up to 96 h. Group A (64097, 64181 and 64186) was different from 64095,64096 and 64156 at $24 \mathrm{~h}$, group B (control) was different from 64096 at $48 \mathrm{~h}$ and Group C (64097, 64181 and 64186) was significantly different from strains 64095 , 64096 and 64156 at $48 \mathrm{~h}(\mathrm{p} \leq 0.05)$.

\section{Metabolic activity of $B$. safensis 64181 and Bacillus sp 64186}

The comparison of the metabolic activity in the biofilms of B. safensis 64181 and Bacillus sp 64186 over time, allowed to identify the hours at which the metabolism of the bacteria is most active, observing that at $48 \mathrm{~h}$ its maximum activity is reached metabolic in in vitro experiments and then after $72 \mathrm{~h}$ begins to decrease. It was 


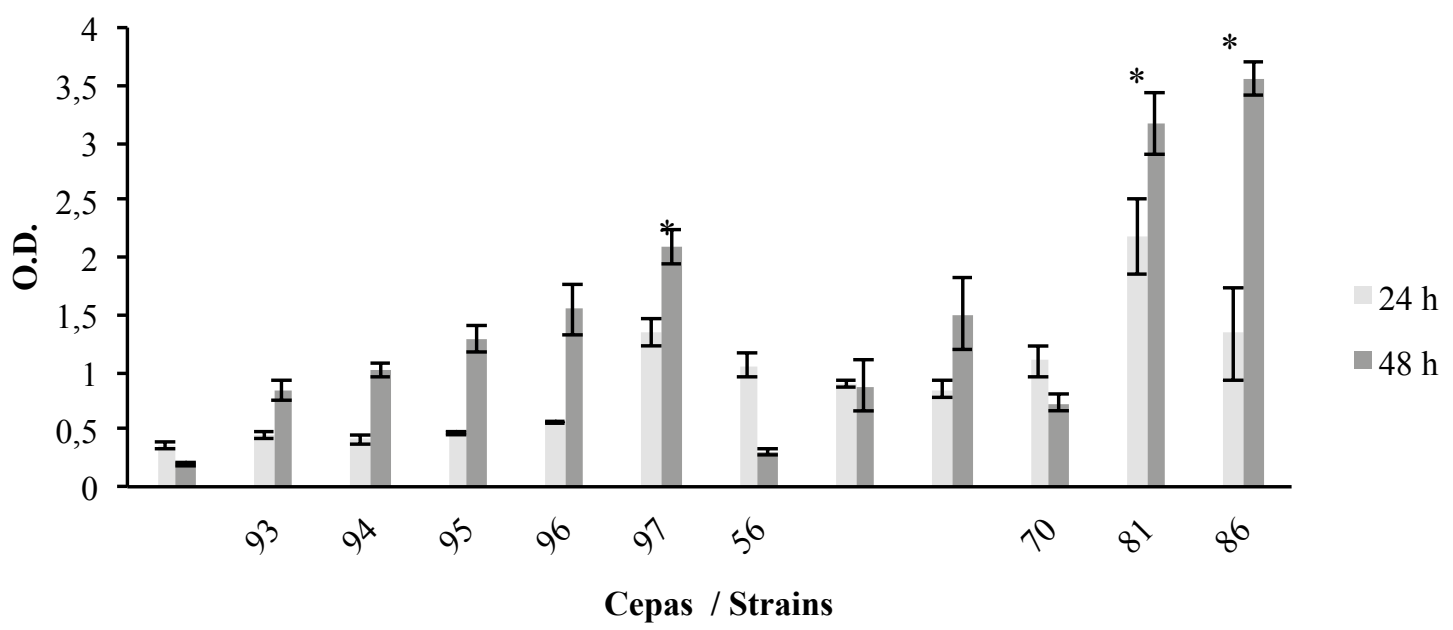

Figura 4. Formación de la biopelícula a 24 y 48 horas; cepas 64093, 64094, 64095, 64096, 64097, 64156, 64100, 64101, 64170, 64181 y 64186 usando como control la cepa de $S$. aureus (SA). Densidad óptica (O.D.); la barra es el \pm 1 error estándar y los asteriscos diferencias significativas entre las cepas y el control, solamente para 48 horas $(p \leq 0,05)$.
Figure 4. Biofilm formation at 24 and 48 hours; strains 64093, 64094, 64095, 64096, 64097, 64156, 64100, 64101, 64170, 64181 and 64186, using the S. aureus (SA) strain as a control. Optical density (O.D.); the bar is \pm 1 standard error and the asterisks show significant differences between the strains and the control, only for 48 hours $(p \leq 0.05)$.

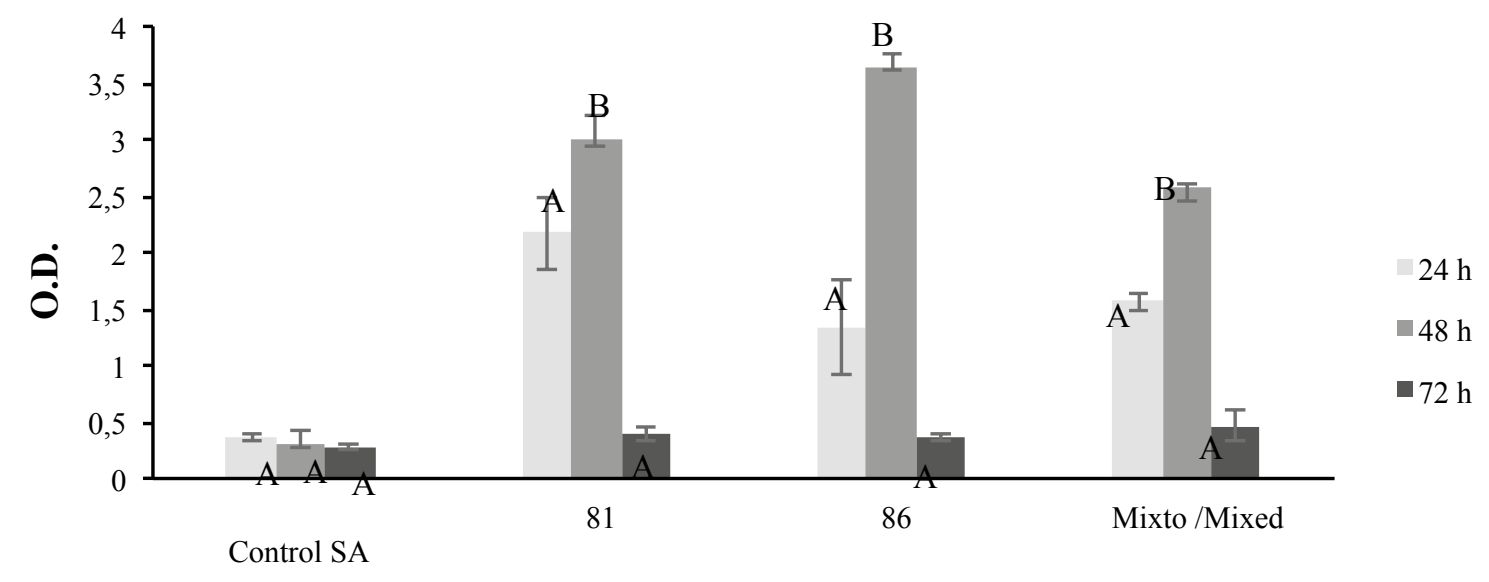

Cepas / Strains

Figura 5. Formación de la biopelícula a las 24,48 y 72 horas para las cepas 64181,64186 y el cultivo mixto, usando como control la cepa de S. aureus (SA). Densidad óptica (O.D.); la barra promedio indica el \pm 1 error estándar y las letras tiempos iguales entre sí, por separado para el control, cepas y mixto $(\mathrm{p} \leq 0,05)$.
Figure 5. Biofilm formation at 24, 48 and 72 hours for strains 64181 , 64186 and mixed culture, using the $S$. aureus (SA) strain as the control. For optical density (O.D.), the average bar indicates \pm 1 standard error and the letters represent equal times, separately for the control, strains, and mixed $(\mathrm{p} \leq 0.05)$. 
de $3,00,3,64$ y 2,58 para las cepas 64181,64186 y el cultivo mixto. Después de este tiempo todas disminuyen.

Para el ensayo de la biopelícula mixta, se observó que la formación de esta fue inferior a la que mostró el tratamiento de cada cepa individual, a pesar que las condiciones de crecimiento fueron las mismas para todos los tratamientos (Figura 5). En relación con los experimentos realizados a diferentes temperaturas para $B$. safensis 64181, Bacillus sp 64186 y juntas (mixto) (Figura 6) se determinó que a $26{ }^{\circ} \mathrm{C}$ y $30{ }^{\circ} \mathrm{C}$ existen diferencias significativas $(\mathrm{p} \leq 0,05)$ en la formación de biopelícula respecto a la temperatura de $28^{\circ} \mathrm{C}$. also observed that in the mixed trial there is little variation between 48 and 72 hours, unlike the individual strains that showed a decrease in cellular metabolic activity (Figure 8).

\section{LIVE/DEAD cell viability staining}

Regarding biofilm formation on coverslips, bacteria were found to be alive in all experiments (LIVE / DEAD staining). It was observed that Bacillus sp 64186 showed a large area coverage, covering most of the surface; however, in some areas it was visualized that the bacteria agglomerated to continue forming the biofilm (Figure 10 e and f).

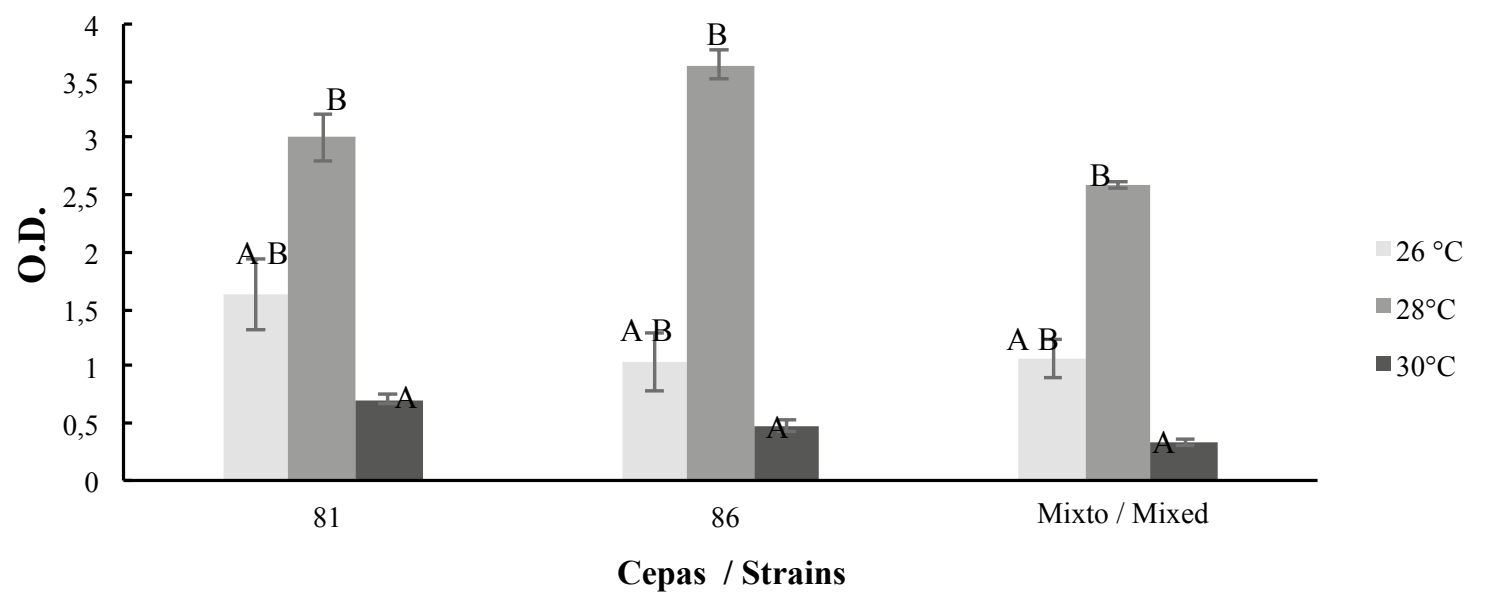

Figura 6. Formación de la biopelícula a 26,28 y $30^{\circ} \mathrm{C}$ durante 48 horas para las cepas de mayor formación B. safensis 64181, Bacillus sp 64186 y Mixto (M). Densidad óptica (O.D.); la barra promedio indica el \pm 1 error estándar promedio y las letras temperaturas iguales entre sí, por separado para las cepas y mixto $(p \leq 0,05)$.
Figure 6. Biofilm formation at 26,28 and $30{ }^{\circ} \mathrm{C}$ during 48 hours for the strains with the highest formation: B. safensis 64181, Bacillus sp 64186 and mixed (M). For optical density (O.D.); the average bar indicates \pm 1 average standard error and the letters indicate temperatures equal to each other, separately for strains and mixed $(\mathrm{p} \leq 0.05)$.

\section{Ensayo general de actividad metabólica con XTT}

Para conocer la actividad metabólica de la biopelícula, también se realizaron ensayos con XTT a todas las cepas y el control negativo (-), observándose que todas tienen una actividad metabólica por encima de 0,6 y en algunas aumenta de las 24 a las $48 \mathrm{~h}$, se resalta nuevamente que las cepas con mayor actividad fueron 64097, 64181 y 64186 (Figura 7). De nuevo, los ensayos con cada cepa mostraron que la mayor actividad metabólica se da a las $48 \mathrm{~h}$, perdurando la actividad hasta las 96 h. El grupo A $(64097,64181$ y 64186) fue diferente
Even in the test with B. safensis 64181 (Figure 10 a) it was observed that it did not adhere to the glass, and the biofilm formed in the liquid-air interface making it difficult to visualize in the microscope; despite this, it was possible to see a matrix where living bacteria were immersed with cell-free spaces that appeared to be forming channel-like structures (Figure 10b). Finally, the mixed biofilm was observed denser than the previous ones and with a large number of bacteria adhered to the matrix, which had a structure 
a 64095, 64096 y 64156 a las 24 h, el grupo B (control) fue diferente a 64096 a las $48 \mathrm{~h}$ y el grupo C (64097, $64181 \mathrm{y}$ 64186) fue significativamente diferente a las cepas 64095 , 64096 y 64156 a las $48 \mathrm{~h}(p \leq 0,05)$. that presented pores and showed that the live bacteria continued to adhere to it (Figure $10 \mathrm{c}$ and $\mathrm{d}$ ).

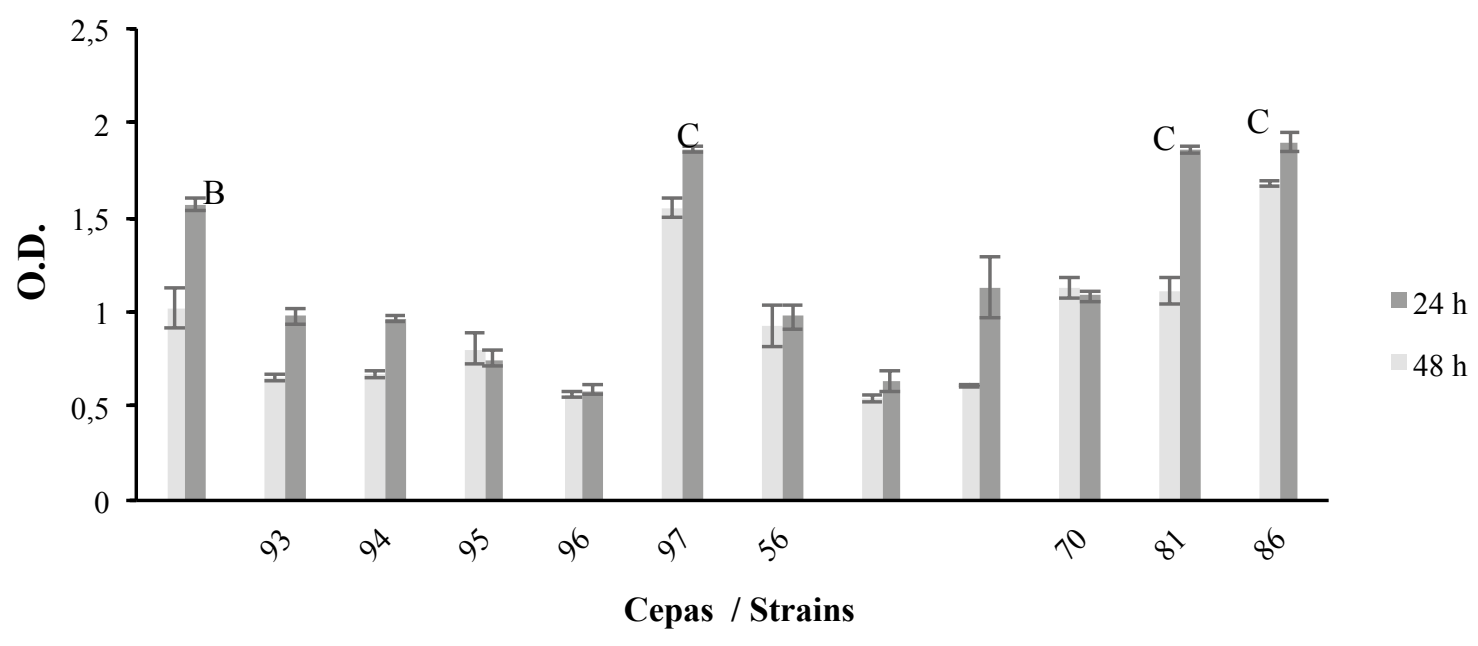

Figura 7. Actividad metabólica durante la formación de la biopelícula a 24 y 48 h (método XTT), para las cepas 64093, 64094, 64095, 64096, $64097,64156,64100,64101,64170,64181,64186$, usando como control la cepa de $S$. aureus (SA). La variable respuesta fue densidad óptica (O.D.). La barra es promedio \pm 1 error estándar y para las letras el resultado de comparaciones estadísticas múltiples entre cepas, por separado para cada tiempo $(p \leq 0,05)$.
Figure 7. Metabolic activity during biofilm formation at 24 and $48 \mathrm{~h}$ (XTT method), for strains 64093, 64094, 64095, 64096, 64097, 64156, $64100,64101,64170,64181,64186$, using the $S$. aureus (SA) strain as the control. The response variable was optical density (O.D.). The average bar \pm 1 standard error and the letters indicate the result of multiple statistical comparisons between strains, separately for each time. See text $(\mathrm{p} \leq 0.05)$.

\section{Actividad metabólica de $B$. safensis 64181 y Bacillus sp} 64186

La comparación de la actividad metabólica en las biopelículas de B. safensis 64181 y Bacillus sp 64186 a través del tiempo, permitió identificar las horas en que el metabolismo de las bacterias está más activo, observándose que a las 48 h se alcanza su máximo de actividad metabólica en experimentos in vitro y luego a partir de las $72 \mathrm{~h}$ empieza a descender. También se observó que en el ensayo mixto hay poca variación entre las 48 y 72 horas, a diferencia de las cepas individuales que presentaron una disminución en la actividad metabólica celular (Figura 8).

Por último, los experimentos variando la temperatura, mostraron que a los $28{ }^{\circ} \mathrm{C}$ existe una mayor actividad metabólica en las bacterias que forman las biopelículas individuales a diferencia de la mixta donde se mantiene igual desde los 26 hasta $\operatorname{los} 28^{\circ} \mathrm{C}$ e incluso sin diferencias significativas con $30^{\circ} \mathrm{C}$ (Figura 9).

\section{DISCUSSION}

\section{Strain identification}

Molecular identification determined that all isolates belong to the Phylum Firmicutes, family Bacillaceae. The phylogenetic analysis showed that they belonged to the genus Bacillus, locating the strains in different groups such as Bacillus cereus, Bacillus pumilus and Bacillus subtilis with an identity percentage of around $99 \%$ with the NCBI reference strains. The nearby strains were used for maximum likelihood phylogenetic analyses. However, the use of other markers such as gyrB and XRE is recommended (Helgason et al., 2000; Punina et al., 2013; Wei et al., 2019) to identify all strains up to the species taxonomic level (Helgason et al., 2000; Punina et al., 2013; Wei et al., 2019).

Based on the results of the identification of the strains studied, we conclude that this was influenced by the selective process carried out with sediment samples 


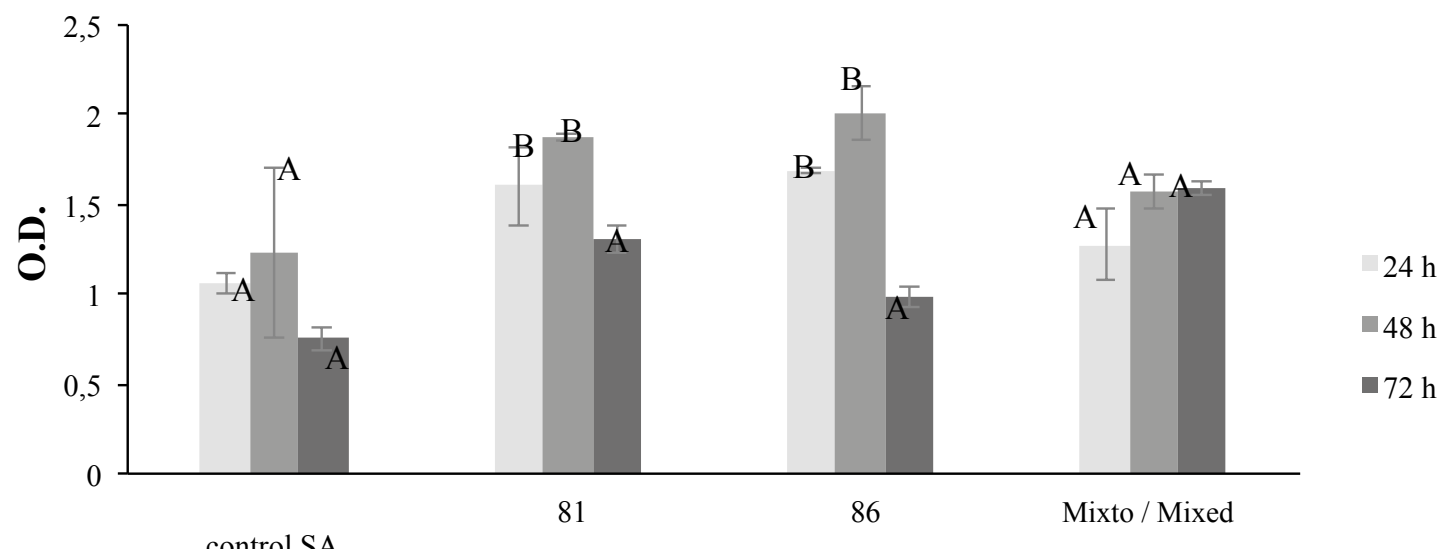

control SA

\section{Cepas / Strains}

Figura 8. Formación de la biopelícula a las 24,48 y 72 horas para las cepas B. safensis 64181, Bacillus sp 64186 y Mixto, usando como control la cepa de $S$. aureus (SA). Densidad óptica (O.D.); la barra promedio indica el \pm 1 error estándar y las letras tiempos iguales entre sí, por separado para control, cepas y mixto $(p \leq 0.05)$.
Figure 8. Biofilm formation at 24, 48 and 72 hours for B. safensis 64181, Bacillus sp 64186 and mixed strains, using the $S$. aureus (SA) strain as a control. Optical density (O.D.); the average bar indicates \pm 1 standard error and the letters indicate equal times, separately for control, strains and mixed $(\mathrm{p} \leq 0.05)$.

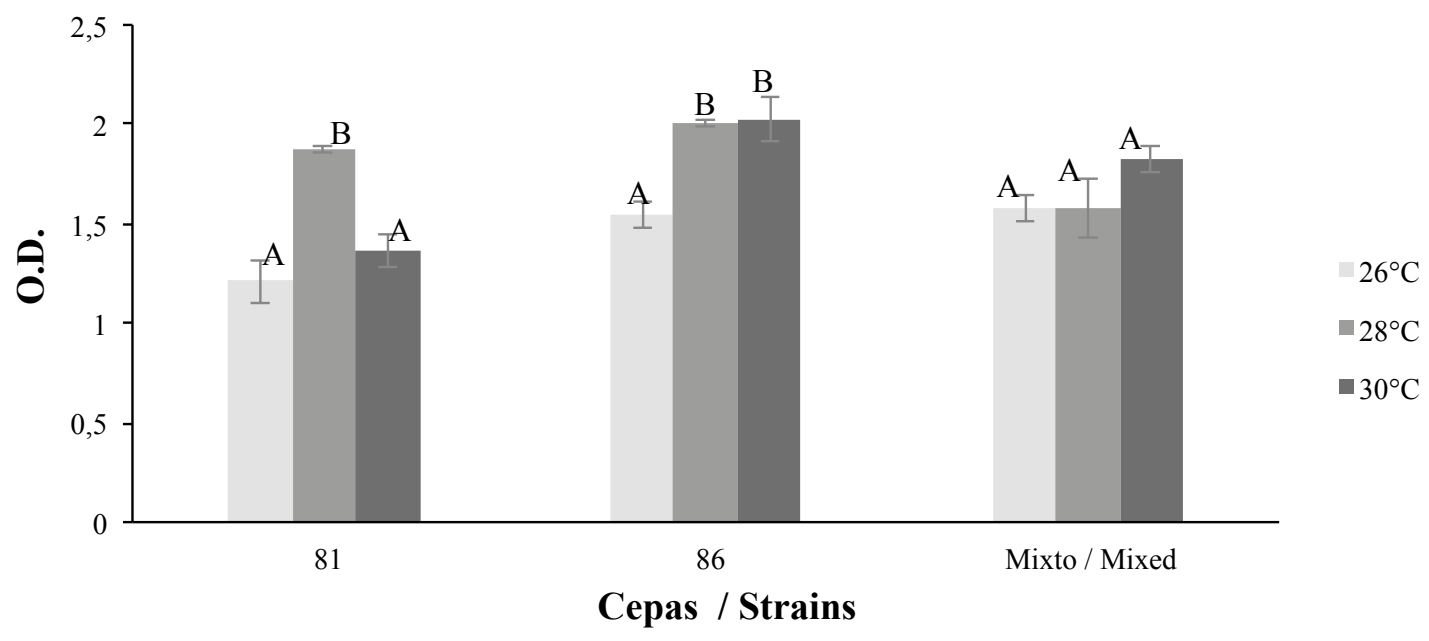

Figura 9. Formación de la biopelícula a 26,28 y $30{ }^{\circ} \mathrm{C}$ durante 48 horas para las cepas de mayor formación B. safensis 64181, Bacillus sp 64186 y Mixto (M). La variable respuesta es densidad óptica (O.D.). La barra promedio indica el \pm 1 error estándar y las letras temperaturas iguales entre sí para las cepas y el mixto $(p \leq 0.05)$.
Figure 9. Biofilm formation at 26, 28 and $30 \mathrm{oC}$ for 48 hours for the strains with the highest formation $B$. safensis 64181 , Bacillus sp 64186 and mixed (M). The response variable is optical density (O.D.). The average bar indicates the \pm 1 standard error and the letters show equal temperatures for strains and mixed $(\mathrm{p} \leq 0.05)$. 


\section{Viabilidad celular Tinción LIVE/DEAD}

En cuanto a la formación de biopelícula en cubreobjetos, se encontró que las bacterias estaban vivas en todos los experimentos (tinción LIVE/DEAD). Se observó que Bacillus sp 64186 mostró una gran cobertura de área, recubriendo la mayor parte de la superficie; sin embargo, en algunas zonas se visualizó que las bacterias se aglomeraban para seguir formado la biopelícula (Figura 10 e y f).

Incluso, en el ensayo con B. safensis 64181 (Figura 10 a) se observó que esta no se adhirió al vidrio, y la biopelícula se formó en la interfase líquido-aire dificultándose la visualización en el microscopio; a pesar de ello se logró ver una matriz donde se encontraban inmersas las bacterias vivas con espacios libres de células que parecían estar formando estructuras similares a canales (Figura $10 \mathrm{~b}$ ). Finalmente, la biopelícula mixta se observó más densa que las anteriores y con gran cantidad de bacterias adheridas a la matriz, la cual tenía una estructura que presentaba poros y mostró que las bacterias vivas seguían adhiriéndose a ella (Figura 10 c y d).

\section{DISCUSIÓN}

\section{Identificación de las cepas}

De acuerdo a la identificación molecular se determinó que todos los aislados pertenecen al phylum Firmicutes, familia Bacillaceae. Del análisis filogenético se obtuvo que pertenecían al género Bacillus ubicándose las cepas en diferentes grupos, tales como el de Bacillus cereus, Bacillus pumilus y Bacillus subtilis con un porcentaje de identidad de alrededor de $99 \%$ con las cepas de referencia del NCBI. Las cepas cercanas fueron las usadas para el análisis filogenético de máxima verosimilitud. Sin embargo, se recomienda el uso de otros marcadores como el gyrB y el XRE (Helgason et al., 2000; Punina et al., 2013) para identificar todas las cepas hasta el nivel taxonómico de especie.

A partir de los resultados de la identificación de las cepas estudiadas, se concluye que esta fue influenciada por el proceso selectivo realizado con las muestras de sedimento en el que se buscó favorecer el crecimiento de bacterias Gram positivas, en especial de actinobacterias con el propósito de identificar actividad antimicrobiana en estas y estudiar los procesos derivados de la comunicación celular quorum sensing como la formación de biopelículas. Aunque en este estudio se diseñó una metodología que consistió en emplear $20 \mathrm{~g}$ de sedimento marino para realizarles un tratamiento con calor a $50^{\circ} \mathrm{C}$, durante 60 minutos, con el fin de eliminar in which we sought to favor the growth of Gram positive bacteria, especially actinobacteria, in order to identify their antimicrobial activity and study the processes derived from cell communication quorum sensing such as biofilm formation. Although, in this study, a methodology was designed that consisted of using $20 \mathrm{~g}$ of marine sediment to be treated with heat at $50^{\circ} \mathrm{C}$, for 60 minutes, in order to eliminate the accompanying vegetative microbiota in the sample, isolates belonging to the genus Bacillus were obtained, which present resistance structures such as endospores, allowing them to tolerate temperatures up to approximately $60{ }^{\circ} \mathrm{C}$ (Kristjansson, 1992). In general, many studies support the use of heat treatments to inhibit the growth of rapidly growing Gram-negative bacteria (Leiva et al., 2015; Matobole et al., 2017), decontamination of sediment samples (Kim, 2013), or selective treatments to support the growth of microbial groups (Bredholt et al., 2008).

\section{Biofilm formation}

To assess the ability to form biofilms of strains isolated from marine sediment, induction and quantification tests were performed using different methods. The first, violet crystal, allowed to measure indirectly each of the strains and thus classify them according to the capacity of adhesion, starting from the comparison of each strain with the negative control $S$. aureus, which according to Martínez and Arévalo (2010) shows decrease in biofilm formation at temperatures below $37^{\circ} \mathrm{C}$. Therefore, strains whose absorbance was less than the negative control were considered non-adherent (Table 2). This method also allowed to evaluate, depending on the biomass, different growth conditions. The second method, quantification by reduction of the XTT, provided information on the metabolic activity of the cells in the biofilm.

Biofilm formation was evaluated at 24 and 48 hours for all 11 isolates, among these the species that showed the most biomass and metabolic activity were Bacillus sp 64097, B. safensis 64181 and Bacillus sp 64186, the last two being selected to produce the greater amount of biomass, these during the tests at different times $(24,48,72$ h), showed that they were more metabolically active at 24 and 48 hours; however, the biofilms were denser at $48 \mathrm{~h}$.

This is explained because each microorganism produces different amounts of exopolysaccharides, which also tend to increase as time goes by, from the beginning of the irreversible adhesion phase of the bacteria to the surface 


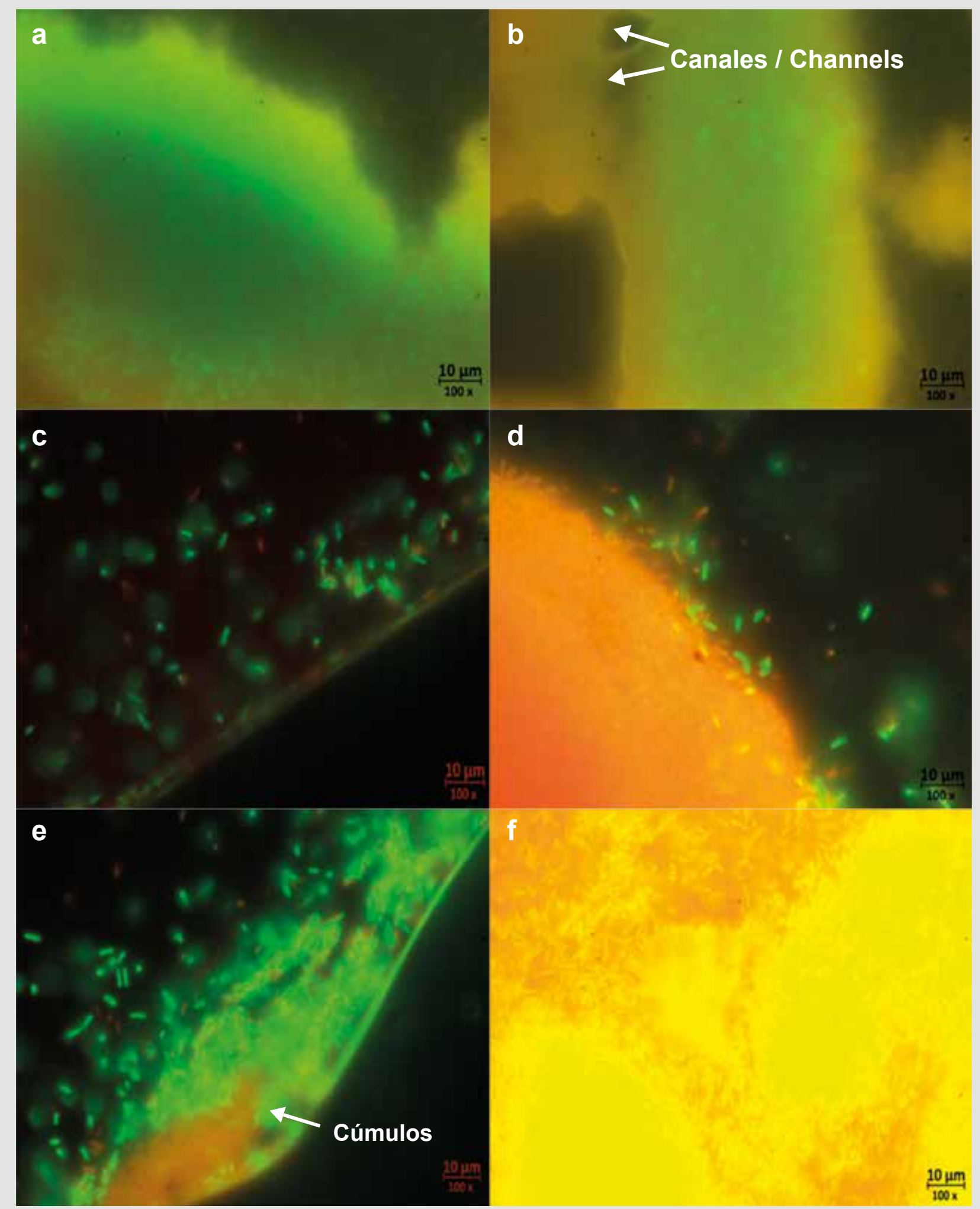

Figura 10. Tinción Live/Dead de las biopelículas después de 24 horas de cultivo sobre cubreobjetos. a. biopelícula de la cepa 64181; b. biopelícula con formaciones similares a canales, cepa 64181; c y d. biopelículas mixta, bacterias adhiriéndose a la matriz; e. bacterias formando cúmulos, cepa 64186; f. Biopelícula de la cepa 64186.

Figure 10. Live/Dead staining of the biofilms after 24 hours of culture on cover slides. a. biofilm of strain 64181 ; b. biofilm with channel-like formations, strain 64181; c and d. mixed biofilms, bacteria adhering to the matrix; e. bacteria forming clusters, strain 64186; f. Biofilm of strain 64186. 
la microbiota vegetativa acompañante en la muestra, se obtuvieron aislados pertenecientes al género Bacillus, bacterias que presentan estructuras de resistencia como las endosporas, lo que les permiten tolerar temperaturas hasta aproximadamente $60{ }^{\circ} \mathrm{C}$ (Kristjansson, 1992). De manera general, muchos estudios respaldan el uso de tratamientos mediante calentamiento, con el fin de inhibir el crecimiento de bacterias Gram negativas de crecimiento rápido (Leiva et al., 2015; Matobole et al., 2017), descontaminación de muestras de sedimentos (Kim, 2013) o tratamientos selectivos para favorecer el crecimiento de grupos microbianos (Bredholt et al., 2008).

\section{Formación de biopelículas}

Para evaluar la capacidad de formar biopelículas de las cepas aisladas del sedimento marino, se realizaron los ensayos de inducción y cuantificación usando diferentes métodos. El primero, cristal violeta, permitió medir de forma indirecta a cada una de las cepas y así clasificarlas según la capacidad de adherencia, partiendo de la comparación de cada cepa con el control negativo $S$. aureus, el cual, según Martínez y Arévalo (2010), muestra disminución en la formación de la biopelícula a temperaturas por debajo de $37^{\circ} \mathrm{C}$. Por lo tanto, las cepas cuya absorbancia fue menor al control negativo fueron consideradas no adherentes (Tabla 2). También este método permitió evaluar, en función de la biomasa, diferentes condiciones de crecimiento. El segundo método, cuantificación por reducción del XTT, proporcionó información sobre la actividad metabólica de las células en la biopelícula.

La formación de la biopelícula se evaluó a 24 y $48 \mathrm{~h}$ para todos los 11 aislados, entre estos las especies que mostraron más biomasa y actividad metabólica fueron Bacillus sp 64097, B. safensis 64181 y Bacillus sp 64186. Las dos últimas fueron seleccionadas por producir la mayor cantidad de biomasa, éstas durante los ensayos a diferentes tiempos $(24,48,72 \mathrm{~h})$, mostraron que eran más activas metabólicamente a las 24 y $48 \mathrm{~h}$; sin embargo, las biopelículas fueron más densas a las $48 \mathrm{~h}$.

Esto se explica porque cada microorganismo produce diferentes cantidades de exopolisacáridos, que además tienden a aumentar a medida que transcurre el tiempo, desde que se inició la fase de adhesión irreversible de las bacterias a la superficie hasta el biofilm maduro (Leriche et al., 2000). Según Flemming y Wingender (2010), los microorganismos representan menos de $10 \%$ de la masa seca, mientras que la matriz puede representar más de 90 $\%$ en la mayoría de los casos. No obstante, la formación de until the mature biofilm (Leriche et al., 2000). According to Flemming and Wingender (2010), microorganisms represent less than $10 \%$ of the dry mass, while the matrix can represent more than $90 \%$ in most cases. However, their formation depends on the ability of bacteria to detect environmental signals; for example, the availability of nutrients (Costerton et al., 1995; Adams and McLean, 1999; Costerton et al., 1999), which are depleted over time, making it difficult to diffuse through the matrix in the biofilm, which generates a gradient that affects the metabolic activity of cells.

For metabolic activity, the results with respect to time show that there are differences between the test of each and together (Mixed). The mixed biofilm over time showed no variation, possibly because the formation of a micro-consortium allows the cells to be in a more dynamic matrix that benefit them to achieve homeostasis, due to the heterogeneity of substances that it presents, and thus adapt to environmental changes or nutrient depletion (Sutherland, 2001; Flemming and Wingender, 2010).

The differences between the amount of biomass and the metabolic activity of the bacteria in relation to the temperature for the monospecies assay, indicates that at $28^{\circ} \mathrm{C}$ the denser biofilm is evidenced, while at the other temperatures the opposite happens, despite being metabolically active, suggesting that temperature may affect other stages of biofilm development such as irreversible adhesion and thus take longer to generate a denser matrix. The mixed test shows a less dense biofilm than those produced by the individual species for each temperature, possibly the high synthesis of $\beta$-galactosidases enzymes by strain 64181 identified as $B$. safensis affects the polysaccharides that make up the mixed matrix (Nath et al., 2012).

In studies with mixed biofilms in natural marine environments, it has been shown that as the temperature increases, the metabolic activity of the biofilm increases (Rao, 2010), as happened with the mixed biofilm test at $30^{\circ}$ $\mathrm{C}$, which increased its metabolic activity with respect to the other temperatures (Figure 9), in addition Yang et al (2013) showed that Bacillus strains at high temperatures had a higher plant growth rate than the biofilm.

Complementary to biofilm assays, the cell viability observed at 24 hours by means of LIVE / DEAD staining (Figure 10), allowed to visualize some biofilm structures and particular characteristics of their formation; for example, species B. safensis 64181 did not adhere to glass and formed the biofilm at the liquid-air interface. In many investigations it has been affirmed that the adhesion of the bacteria to the 
éstas depende de la capacidad de las bacterias para detectar señales ambientales; por ejemplo, la disponibilidad de nutrientes (Costerton et al., 1995; Adams y McLean, 1999; Costerton et al., 1999), los cuales se van agotando con el transcurso del tiempo, dificultado su difusión a través de la matriz en la biopelícula, lo que genera un gradiente que afecta la actividad metabólica de las células.

Para la actividad metabólica, los resultados respecto al tiempo evidencian que existen diferencias entre el ensayo de cada una y juntas (mixto). La biopelícula mixta a través del tiempo no mostró variación, posiblemente porque la formación de un microconsorcio permite a las células estar en una matriz más dinámica que les favorezca para alcanzar una homeostasis, debido a la heterogeneidad de sustancias que esta presenta, y así adaptarse a los cambios ambientales o al agotamiento de nutrientes (Sutherland, 2001; Flemming y Wingender, 2010).

Las diferencias entre la cantidad de biomasa y la actividad metabólica de las bacterias en relación con la temperatura para los ensayos monoespecie indican que a $28^{\circ} \mathrm{C}$ se evidencia la biopelícula más densa, mientras que a las otras temperaturas sucede lo contrario, a pesar de estar activas metabólicamente, sugiriendo que la temperatura puede afectar otras etapas del desarrollo de las biopelículas como la adhesión irreversible y así tardar más tiempo para generar una matriz más densa. El ensayo mixto muestra una biopelícula menos densa que las producidas por las especies individuales para cada temperatura, posiblemente la alta síntesis de enzimas de $\beta$-galactosidasas por parte de la cepa 64181, identificada como B. safensis, afecta a los polisacáridos que conforman la matriz mixta (Nath et al., 2012). En estudios realizados con biopelículas mixtas en ambientes naturales marinos, se ha demostrado que a medida que se aumenta la temperatura, la actividad metabólica de la biopelícula incrementa (Rao, 2010), al igual que ocurrió con el ensayo de la biopelícula mixta a $30^{\circ} \mathrm{C}$, el cual incrementó su actividad metabólica respecto a las otras temperaturas (Figura 9). Además, Yang et al (2013) demostraron que cepas de Bacillus en altas temperaturas tenían una mayor tasa de crecimiento planctónico que de la biopelícula.

Complementario a los ensayos de biopelículas, la viabilidad celular observada a las dos mediante la tinción LIVE/DEAD (Figura 10), facilitó visualizar algunas estructuras de las biopelículas y características particulares de su formación; por ejemplo, la especie B. safensis 64181 no se adhirió al vidrio y formó la biopelícula en la interfase líquido- aire. En muchas investigaciones se ha afirmado que la adherencia de las bacterias a las superficies es directamente surfaces is directly proportional to the roughness of the same (Characklis and Marchall, 1990). However, irreversible adhesion of bacteria depends on other factors such as the interaction between the nature of the material and the cell; for example, the type of hydrophobic interaction that occurs between the bacteria and the surface could help it overcome repulsive forces and irreversibly join it (Donlan, 2002).

Despite this, these statements are contradictory in the literature, because there are no standardized methodologies to measure the nature of the materials, although it is suggested that microorganisms adhere more quickly to hydrophobic and non-polar surfaces such as Teflon, polystyrene and other plastics, than hydrophilic materials such as glass or metals (Soler, 2018). In many Gram-positive bacteria, such as those of the Bacillus genus, the bacterial surface is characterized by being hydrophobic and having an affinity to these materials.

As for the biofilms of Bacillus sp 64186 and the mixed one, a dense matrix was observed that presented in some areas clusters of bacteria and in some cases the staining was visualized red. This is because the matrix composition is formed by extracellular DNA (eDNA), which has commonly been considered a remnant of the lysed cells, although it occurs in some cases in very high quantities (Whitchurch et al., 2002; Flemming et al., 2007). Allesen-Holm et al. (2006) found that in Pseudomonas aeruginosa, the eDNA that was part of the matrix was derived from genomic DNA, and that it was organized in such a way that it served as a grid-shaped support structure for the biofilm; therefore, it is attributed a structural role.

\section{ACKNOWLEDGEMENTS}

To the Marine and Coastal Research Institute "José Benito Vives De Andréis" -Invemar; to Universidad Nacional de Colombia Sede Caribe; to the Ministry of Environment and Sustainable Development -MADS, for financing this project. This research was framed in the project "Search for active substances of microorganisms of coastal marine environments" for their potential application in next fields: health, industry, agriculture and environment (File RGE 0158-5), framework contract for access to genetic resources and derived product No. 123, held between the Ministry of Environment and Sustainable Development -MADS and Invemar. Also to the Marine Bioprospecting Line of the Program for the Valuation and Use of Marine Resources where the project was carried out. Contribution Cecimar $\mathrm{N}^{\circ} 494$ and Invemar $\mathrm{N}^{\circ} 1236$. 
proporcional a la rugosidad de la misma (Characklis y Marchall, 1990). Sin embargo, la adherencia irreversible de las bacterias depende de otros factores como la interacción entre la naturaleza del material y célula; por ejemplo, el tipo de interacción hidrofóbica que se produce entre la bacteria y la superficie podría ayudarla a superar las fuerzas repulsivas y unirse irreversiblemente a ésta (Donlan, 2002).

A pesar de ello, estas afirmaciones son contradictorias en la literatura, debido a que no hay metodologías estandarizadas para medir la naturaleza de los materiales, pese a que se sugiere que los microorganismos se adhieren más rápidamente a superficies hidrófobas y no polares como el teflón, poliestireno y otros plásticos, que a materiales hidrófilos como el vidrio o los metales (Soler, 2018). En muchas bacterias Gram positivas, como las del género Bacillus, la superficie bacteriana se caracteriza por ser hidrófoba y tener afinidad a estos materiales.

En cuanto, a las biopelículas de Bacillus sp 64186 y la mixta, se observó una matriz densa que presentaba en algunas zonas cúmulos de bacterias y en algunos casos la tinción se visualizaba roja. Esto se debe a que la composición de la matriz está formada por ADN extracelular (eADN), que comúnmente ha sido considerado un remanente de las células lisadas, aunque se produce en algunos casos en cantidades muy altas (Whitchurch et al., 2002; Flemming et al., 2007). Allesen-Holm et al. (2006) descubrieron que en Pseudomonas aeruginosa el eADN que formaba parte de la matriz se deriva de ADN genómico, y que este se organizaba de tal forma que servía como una estructura de soporte en forma de rejilla para la biopelícula; por lo tanto, se le atribuye un papel estructural.

\section{AGRADECIMIENTOS}

Al Instituto de Investigaciones Marinas y Costeras "José Benito Vives De Andréis" -Invemar; a la Universidad Nacional de Colombia Sede Caribe; al Ministerio de Ambiente y Desarrollo Sostenible -MADS a través del Banco de Proyectos de Inversión Nacional - BPIN, por financiar el presente proyecto. Esta investigación estuvo enmarcada en el proyecto Búsqueda de sustancias activas de microorganismos de ambientes marino costeros para su potencial aplicación en los sectores: salud, industria, agropecuario y ambiente (Expediente RGE 0158-5), contrato marco de acceso a recurso genético y producto derivado No. 123, celebrado entre MADS e Invemar. También a la Línea de Bioprospección Marina del Programa de Valoración y Aprovechamiento de los Recursos Marinos del Invemar donde se llevó a cabo el proyecto. Contribución $\mathrm{N}^{\circ}$ 494 del Cecimar y $N^{\circ} 1236$ del Invemar. 


\section{BIBLIOGRAFÍA / LITERATURE CITED}

Adams, J. L and R. C. McLean. 1999. Impact of rpoS deletion on Escherichia coli biofilms. Appl. Environ. Microbiol., 65:4285 -4287.

Allesen-Holm, M., J.S. M. K. Webb, K. Staffan, M. Søren, M. Givskov and T. Tolker-Nielsen. 2006. A characterization of DNA release in Pseudomonas aeruginosa cultures and biofilms. Mol. Microbiol., 59:114-1128.

Azam, F., T. Fenchel, J. G. Field, J. S. Gray, L. A. Meyer-Reil and F. Thingstad. 1983. The ecological role of water-column microbes in the sea. Mar. Ecol. Prog. Ser., 10: 257-263.

Bredholt, H., E. Fjærvik, G. Johnsen and S.B. Zotchev. 2008. Actinomycetes from sediments in the Trondheim Fjord, Norway: diversity and biological activity. Mar. Drugs , 6:12-24.

Cao, S., J. Wang, H. Chen and D. Chen. 2011. Progress of marine biofouling and antifouling technologies. Chin. Sci. Bull., 56: 598-612.

Characklis, W. G., G.A. McFeters and K.C. Marshall. 1990. Physiological ecology in biofilm systems. John Wiley, New York. 816 p.

Costerton, J.W., Z. Lewandowski, D.E. Caldwell, D.R. Korber and H.M. Lappin-Scott. 1995. Microbial biofilms. An. Rev. Microbiol., $49: 711-45$.

Costerton, J.W., P.S Stewart and P. Greenberg.1999. Bacterial biofilms: A common cause of persistent infections. Science, 80:1318-22.

Dang, H., and C.R. Lovell. 2016. Microbial surface colonization and biofilm development in marine environments. Microbiol. Mol. Biol. Rev., 80: 91-138.

Dang, H., Li, T., M. Chen and G. Huang. 2008. Cross-ocean distribution of Rhodobacterales bacteria as primary surface colonizers in temperate coastal marine waters. Appl. Environ. Microbiol., 74: 52-60.

Dashti, A.A., M.M. Jadaon, A.M. Abdulsamad and H.M. Dashti. 2009. Heat treatment of bacteria: A simple method of DNA extraction for molecular techniques. Kuwait Med. J., 41: 117-122.

De Carvalho, C.R. and M.J. Caramujo. 2012. Lipids of prokaryotic origin at the base of marine food webs. Mar. Drugs, 10: $2698-2714$.

Donlan, M. R. 2002. Biofilms: Microbial Life on Surfaces. Emerg Infect Dis, 8: 881-890.

Flemming, H.-C. and J. Wingender. 2010. The biofilm matrix. Nat. Rev. Microbiol, 8: 623-632.

Flemming, H.-C., T. R. Neu and D.J . Wozniak. 2007. The EPS Matrix: The «House of Biofilm Cells».J Bacteriol., 22: 7945-7947.

Hadfield, M.G. 2011. Biofilms and marine invertebrate larvae: what bacteria produce that larvae use to choose settlement sites. An. Rev. Mar. Sci., 3: 453-470. Hasegawa M., H. Kishino and T.A. Yano. 1985. Dating of the human ape splitting by a molecular clock of mitochondrial-DNA. J. Mol. Evol., 22:160-174.

Hawley, A.K., M.K. Nobu, J.J. Wright, W.E. Durno, C. Morgan-Lang and B. Sage. 2017. Diverse Marinimicrobia bacteria may mediate coupled biogeochemical cycles along eco-thermodynamic gradients. Nature, 8: 1507p.

Helgason, E., O.A. Okstad, D.A. Caugant, H.A. Johansen and A. Fouet. 2000. Bacillus anthracis, Bacillus cereus, and Bacillus thuringiensis-one species on the basis of genetic evidence. Appl. Environ. Microbiol., 66: 2627-2630.

Kim, S.K. 2013. Marine microbiology: bioactive compounds and biotechnological applications. Willey-VCH, 580p.

Kolenbrander, E., N. Andersen, S. Blehert, G. Egland, S. Foster and J. Parmer. 2002. Communication among oral bacteria. Microbiol. Mol. Biol. Rev., 66: 486-505. Kristjansson, J. 1992. Thermophilic Bacteria. CRC, New York. 52 p.

Kuramitsu, K., X. He, R. Lux, H. Anderson and Y. Shi. 2007. Interspecies interactions within oral microbial communities. Microbiol. Mol. Biol. Rev., 71: 653-670.

Lau, S., K.C. Mak, K.F. Chen and P.Y. Qian. 2002. Bioactivity of bacterial strains isolated from marine biofilms in Hong Kong waters for the induction of larval settlement in the marine polychaete Hydroides elegans. Mar. Ecol. Prog. Ser., 226: 301-310.

Lee, J.W., J.H. Nam, Y.H. Kim, K.H. Lee and D.H. Lee. 2008. Bacterial communities in the initial stage of marine biofilm formation on artificial surfaces. J. Microbiol., 46: 174-182.

Leiva, S., P. Alvarado, Y. Huang, J. Wang and I. Garrido. 2015. Diversity of pigmented Gram-positive bacteria associated with marine macroalgae from Antarctica. FEMS Microbiol. Let., 362: 206.

Leriche V. and P.S. 2000. Use of an enzyme-linked lectinsorbent assay to monitor the shift in polysaccharide composition in bacterial biofilms. Appl Environ Microbiol, 66:1851-1856.

León, J., L. Liza, I. Soto, D. Cuadra, L. Patiño and R. Zerpa. 2007. Actinomycetes bioactivos de sedimento marino de la costa central del Perú. Rev. Per. Biol., 14: 259-270.

Little, B.J., J.S. Lee and R.I. Ray. 2008. The influence of marine biofilms on corrosion: a concise review. Electrochim. Acta, 54: 2-7.

Lobelle, D y M. Cunliffe. 2011. Early microbial biofilm formation on marine plastic debris. Mar. Pollut. Bull., 62: 197-200.

Martínez, S. y A. Acosta. 2016. Cambio temporal en la estructura de la comunidad coralina del área de Santa Marta - Parque Nacional Natural Tayrona (Caribe colombiano). Bull. Mar. Coast. Res., 34:161-191.

Martínez-Díaz, J. y C. Arévalo-Ferro. 2010. Evaluación de un bioensayo para medir la inhibición de biopelículas bacterianas. Universidad Nacional de Colombia, Bogotá. 103 p.

Matobole, R.M., L.J. van Zyl, S. Parker-Nance, M. T. Davies-Coleman and M. Trindade. 2017. Antibacterial activities of bacteria isolated from the marine sponges Isodictya compressa and Higginsia bidentifera collected from Algoa Bay, South Africa. Mar. Drugs, 15: 47. 
Nath, A., S. Sarkar, M. Maitr, C. Bhattacharjee and R. Chowdhury. 2012. An experimental study on production of intracellular $\beta$-galactosidase at different conditions by batch process using isolated Bacillus safensis (JUCHE 1) and characterization of synthesized $\beta$-galactosidase. J. Inst. Eng. India, 93: 55-60.

Nazar, J. 2007. Biofilms bacterianos. Rev. Otorrinolaring. Cir. Cab. Cuello, 67: 161-172.

Nowak, M. and P. Kurnatowski. 2009. Biofilm caused by fungi structure, quorum sensing, morphogenetic changes, resistance to drugs. Wiad Parazytol., 55:19-25.

Paerl, H.W and J.L. Pinckney. 1996. A mini-review of microbial consortia: their roles in aquatic production and biogeochemical cycling. Microbiol. Ecol., 31: 225-247.

Pruesse E., J. Peplies and O.F. Glöckner, 2012. SINA: Accurate high-throughput multiple sequence alignment of ribosomal RNA genes. Bioinformatics, 28: $1823-1829$.

Punina, N.V., V.S. Zotov, A.L. Parkhomenko, T.U. Parkhomenko and A.F. Topunov. 2013. Genetic diversity of Bacillus thuringiensis from different geoecological regions of Ukraine by analyzing the 16S rRNA and gyrB genes and by AP-PCR and saAFLP. Acta Nat., 5:90-100.

Rao, T. 2010. Comparative effect of temperature on biofilm formation in natural and modified marine environment. Aquatic Environ., 44: 463-478.

Raver, J. 2000. Interspecific Transfer of Streptomyces giant linear plasmids in sterile attended soil microcosms. Appl. Environ. Microbiol., 66: 529-534.

Rocha, L.C., J.R. de Oliveira, B. Vacondio, G.N. Rodrigues, M.H. Seleghim and A.L. Porto. 2013. Bioactive marine microorganisms for biocatalytic reactions in organic compounds. 453-490. In: Se-Kwon, Kim. (Ed.). Marine Microbiology, Wiley-VCH, Weinheim, Germany. 549 p.

Rodriguez, R.A. and C.E. Epifanio. 2000. Multiple cues for induction of metamorphosis in larvae of the common mud crab Panopeus herbstii. Mar. Ecol., 195:221-229.

Romero, M y A. Otero. 2010. Interceptación de señales de comunicación bacteriana tipo N-acilhomoserín lactonas (AHLs) en bacterias aisladas del medio marino. Universidad de Santiago de Compostela, Santiago de Compostela, España. 220 p.

Rooney, A.P., N.P.J. Price, C. Ehrhardt, J.L. Swezey and J.D. Bannan. 2009. Phylogeny and molecular taxonomy of the Bacillus subtilis species complex and description of Bacillus subtilis subsp. In a quosorum subsp. nov. INT J SYST EVOL MICR, 59: 2429-2436.

Soler Arango, J. 2018. Inactivación de biofilms de Pseudomonas aeruginosa mediante plasma frío a condiciones atmosféricas. Universidad Nacional de la Plata, La Plata, Argentina. 208 p.

Sowmya, N., M.S. Thakur and H.K. Manonmani. 2012. Rapid and simple DNA extraction method for the detection of enterotoxigenic Staphylococcus aureus directly from food samples: comparison of PCR and LAMP methods: Rapid and simple DNA extraction method. J. Appl. Microbiol., 113: 106-113.

Stepanović, S., D. Vuković, I . Dakic, B. Savic and M. Svabic-Vlahovic. 2000. Quantification of biofilm in microtiter plates: overview of testing conditions and practical recommendations for assessment of biofilm production by staphylococci. J. Microbiol. Meth., 175-179.

Torres-Beltrán, M.F., Cardoso-Martínez, N. Millán-Aguiñaga, A. Becerril-Espinosa e I. Soria-Mercado. 2012. Evaluación del golfo de California como una fuente potencial de actinobacterias marinas bioactivas. Rev. Cienc. Mar., 38: 609- 624.

Wei, S., R. Chelliah, B. Park, S.H. Kim, F. Forghani, M.S. Cho and D.H Oh. 2019. Differentiation of Bacillus thuringiensis from Bacillus cereus group using a unique marker based on real-time PCR. Front Microbiol., 10:883.

Weisburg, W.G., S.M. Barns, D.A. Pelletier and D.J. Lane. 1991. 16S ribosomal DNA amplification for phylogenetic study. J. Bacteriol., $173: 697-703$.

Whitchurch, C.B., P.C. Ragas and J.S. Mattick. 2002. Extracellular DNA required for bacterial biofilm formation. Science, $295: 1487$.

Yang, Q., D. Wilson, X. Chen y L. Shi. 2013. Investigación experimental de las interacciones entre el campo de la temperatura y la bioincrustación en una corriente de aguas residuales tratadas sintéticamente. Biofouling, 29: 513-23. 